Prepared in cooperation with the U.S. Fish and Wildlife Service and North Dakota Department of Health

\title{
Assessment of Water-Quality Data from Long Lake National Wildlife Refuge, North Dakota—2008 Through 2012
}

Scientific Investigations Report 2013-5183 
Cover. Unit 2 of Long Lake National Wildlife Refuge; August 2012. Photograph by U.S. Geological Survey. 


\section{Assessment of Water-Quality Data from Long Lake National Wildlife Refuge, North Dakota—2008 Through 2012}

By Brian A. Tangen, Raymond G. Finocchiaro, Robert. A. Gleason, Michael J. Rabenberg, Charles F. Dahl, and Michael J. Ell

Prepared in cooperation with the U.S. Fish and Wildlife Service and North Dakota Department of Health

Scientific Investigations Report 2013-5183 


\title{
U.S. Department of the Interior SALLY JEWELL, Secretary
}

\section{U.S. Geological Survey Suzette M. Kimball, Acting Director}

\author{
U.S. Geological Survey, Reston, Virginia: 2013
}

For more information on the USGS - the Federal source for science about the Earth, its natural and living resources, natural hazards, and the environment, visit http://www.usgs.gov or call 1-888-ASK-USGS.

For an overview of USGS information products, including maps, imagery, and publications, visit http://www.usgs.gov/pubprod

To order this and other USGS information products, visit http://store.usgs.gov

Any use of trade, firm, or product names is for descriptive purposes only and does not imply endorsement by the U.S. Government.

Although this information product, for the most part, is in the public domain, it also may contain copyrighted materials as noted in the text. Permission to reproduce copyrighted items must be secured from the copyright owner.

Suggested citation:

Tangen, B.A., Finocchiaro, R.G., Gleason, R.A., Rabenberg, M.J., Dahl, C.F., and Ell, M.J., 2013, Assessment of waterquality data from Long Lake National Wildlife Refuge, North Dakota—2008 through 2012: U.S. Geological Survey Scientific Investigations Report 2013-5183, 28 p., http://dx.doi.org/10.3133/sir20135183. 


\section{Acknowledgments}

The following U.S. Fish and Wildlife Service personnel were instrumental in initiating this project and performing field work: Neal Brown, Natoma Buskness, Cheryl Jacobs, Wayne King, Gregory Knutsen, Murray Laubhan, and Paul Van Ningen. We thank the North Dakota Department of Health for providing Long Lake Creek data from a complementary study. We also thank Cami Dixon for comments on a previous version of this report.

We thank the following U.S. Geological Survey Northern Prairie Wildlife Research Center personnel for performing field work and data collection: Clinton Helms, Andrew Lillijord, Peter Mockus, Jacob Niemeier, Sarah Paycer, Mike Pederson, Matthew Retka, Mark Schaffner, Tim Spivey, Lee Tafelmeyer, Amy Timm, and Colin Wilson. We thank the staff from the U.S. Geological Survey North Dakota Water Science Center for collecting streamflow measurements. We also thank Robert Lundgren for comments on a previous version of this report. 


\section{Contents}

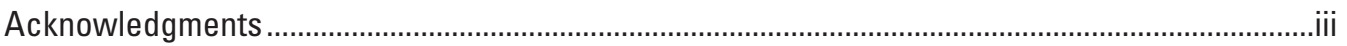

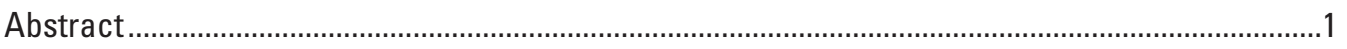

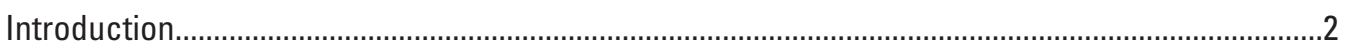

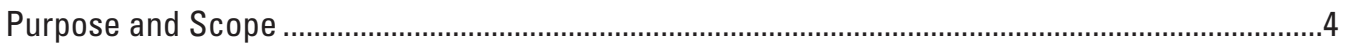

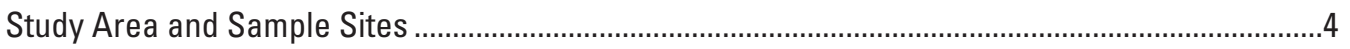

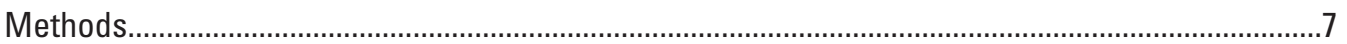

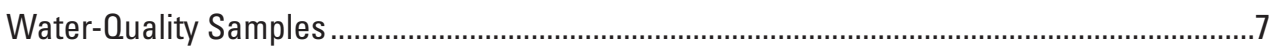

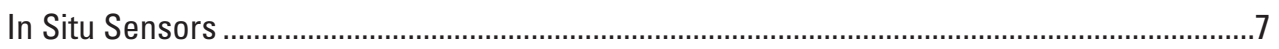

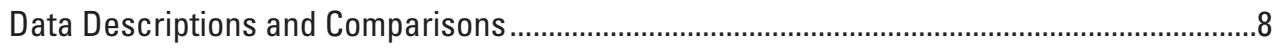

Ions, Trace Metals, and Nutrients.........................................................................

Temporal Patterns and Spatial Variability ...................................................................

Concentrations of Chemical Constituents .............................................................................

lons

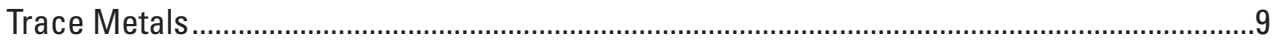

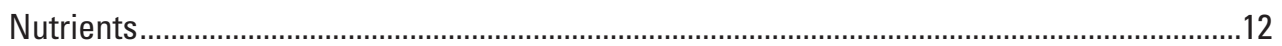

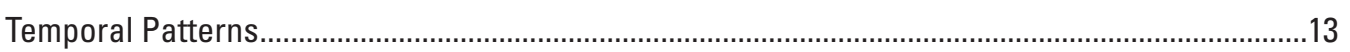

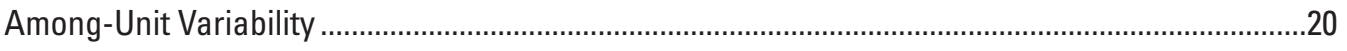

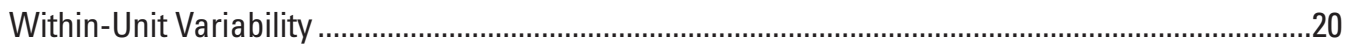

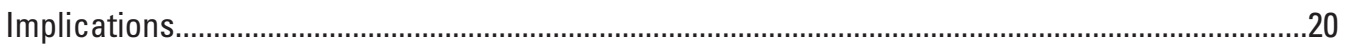

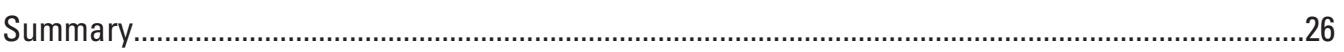

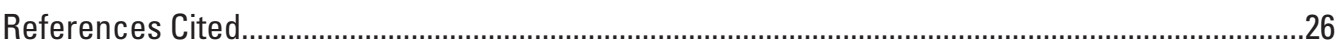

Appendix 1. Water chemistry data of Long Lake Creek upstream of Long Lake and Unit 1, Unit 2, Unit 2 Marsh, and Unit 3 of Long Lake National Wildlife Refuge, North Dakota, from 2008 through 2012.

http://pubs.usgs.gov/sir/2013/5183/downloads/appendix_1.xlxs

Appendix 2. Specific conductance and water temperature of Unit 1, Unit 2, Unit 3, and Unit 2 Marsh of Long Lake National Wildlife Refuge and Long Lake Creek upstream of Long Lake, North Dakota, from 2008 through 2012. http://pubs.usgs.gov/sir/2013/5183/downloads/appendix_2.x/xs

\section{Figures}

1. Map showing location of Long Lake National Wildlife Refuge.

2. Map showing locations of Long Lake National Wildlife Refuge water management units (Unit 1, Unit 2, Unit 3, Unit 2 Marsh), dikes (A dike, B dike, Unit 2 Marsh Dike, C dike), and study sample sites.

3. Graphs showing total annual precipitation for south-central North Dakota, and mean annual air temperature for south-central North Dakota.

4. Graphs showing mean concentrations of cations and anions from water-quality samples of Long Lake Creek and Unit 1, Unit 2, Unit 2 Marsh, and Unit 3 of Long Lake National Wildlife Refuge, 2008 through 2012

5. Graph showing aluminum concentrations from water-quality samples of Long Lake Creek and Unit 1, Unit 2, Unit 2 Marsh, and Unit 3 of Long Lake National Wildlife Refuge, 2008 through 2012, in relation to acute and chronic standard values. 
6. Graph showing copper concentrations from water-quality samples of Long Lake Creek and Unit 1, Unit 2, Unit 2 Marsh, and Unit 3 of Long Lake National Wildlife

Refuge, 2008 through 2012, in relation to acute and chronic standard values...

7. Graph showing specific conductance from in situ sensors located at Long Lake Creek and Unit 1, Unit 2, Unit 2 Marsh, and Unit 3 of Long Lake National Wildlife Refuge, 2008 through 2012.

8. Graph showing water level and specific conductance for Long Lake Creek upstream of Long Lake National Wildlife Refuge, 2008 through 2012.

9. Graph showing water level and specific conductance for Unit 1 of Long Lake National Wildlife Refuge, 2008 through 2012.

10. Graph showing water level and specific conductance for Unit 2 of Long Lake National Wildlife Refuge, 2008 through 2012.

11. Graph showing water level and specific conductance for Unit 2 Marsh of Long Lake National Wildlife Refuge, 2008 through 2012

12. Graph showing water level and specific conductance for Unit 3 of Long Lake National Wildlife Refuge, 2008 through 2012. Unit 3 was dry during 2008.

13. Graph showing specific conductance from water-quality samples collected across 68 sample periods for the 4 sample sites (symbols) distributed around Unit 1 of Long Lake National Wildlife refuge, 2008 through 2012

14. Graph showing specific conductance from water-quality samples collected across 68 sample periods for the 6 sample sites (symbols) distributed around Unit 2 of Long Lake National Wildlife refuge, 2008 through 2012

15. Graph showing specific conductance from water-quality samples collected across 67 sample periods for the 3 sample sites (symbols) distributed around Unit 2 Marsh of Long Lake National Wildlife refuge, 2008 through 2012.

16. Graph showing specific conductance from water-quality samples collected across 59 sample periods for the 5 sample sites (symbols) distributed around Unit 3 of Long Lake National Wildlife refuge, 2009 through 2012

17. Graph showing mean arsenic concentrations from water-quality samples of Unit 1 , Unit 2, Unit 2 Marsh, and Unit 3 of Long Lake National Wildlife Refuge, 2008 through 2012

18. Graph showing specific conductance from hand-held loggers deployed at Long Lake Creek and Unit 1, Unit 2, Unit 2 Marsh, and Unit 3 of Long Lake National Wildlife Refuge, 2008 through 2012

\section{Tables}

1. Estimated mean inflow from Long Lake Creek and outflow from Long Lake during 2008 through 2012

2. Range of sample dates, number of sample sites, sample site number, and number of biweekly water-quality samples collected at Long Lake from 2008 through 2012 ........6

3. Ranges of dates that in situ sensors and data loggers were installed at Long Lake, 2008 through 2012

4. Reporting criteria for water-quality characteristics, properties, and constituents analyzed in water samples collected from Long Lake

5. Summary statistics for ions and water-quality constituents for water samples collected from Long Lake, 2008 through 2012

6. North Dakota water-quality criteria for ions, trace metals, and nutrients, and the percent of exceedances for water samples from Long Lake, 2008 through 2012. 
7. Summary statistics for trace metals collected from Long Lake, 2008 through 2012 .......12

8. Summary statistics for nutrients from water samples collected from Long Lake, 2008 through 2012

\section{Conversion Factors}

\begin{tabular}{lcl}
\multicolumn{1}{c}{ SI to Inch/Pound } & \multicolumn{1}{c}{ By } & To obtain \\
\hline centimeter $(\mathrm{cm})$ & Length & inch (in.) \\
meter $(\mathrm{m})$ & 0.3937 & foot (ft) \\
kilometer $(\mathrm{km})$ & 3.281 & mile (mi) \\
\hline & 0.6214 & acre \\
\hline hectare $($ ha) & Area & acre \\
square kilometer $\left(\mathrm{km}^{2}\right)$ & 2.471 & square mile (mi $\left.{ }^{2}\right)$ \\
square kilometer $\left(\mathrm{km}^{2}\right)$ & 247.1 & \\
\hline & 0.3861 & quart (qt) \\
\hline liter $(\mathrm{L})$ & Volume & ounce, avoirdupois (oz) \\
\hline
\end{tabular}

Specific conductance is given in microsiemens per centimeter at 25 degrees Celsius $(\mu \mathrm{S} / \mathrm{cm}$ at $\left.25^{\circ} \mathrm{C}\right)$.

Concentrations of chemical constituents in water are given either in milligrams per liter (mg/L) or micrograms per liter $(\mu \mathrm{g} / \mathrm{L})$.

Temperature in degrees Celsius $\left({ }^{\circ} \mathrm{C}\right)$ may be converted to degrees Fahrenheit $\left({ }^{\circ} \mathrm{F}\right)$ as follows:

${ }^{\circ} \mathrm{F}=\left(1.8 x^{\circ} \mathrm{C}\right)+32$

Temperature in degrees Fahrenheit $\left({ }^{\circ} \mathrm{F}\right)$ may be converted to degrees Celsius $\left({ }^{\circ} \mathrm{C}\right)$ as follows: ${ }^{\circ} \mathrm{C}=\left({ }^{\circ} \mathrm{F}-32\right) / 1.8$

Vertical coordinate information is referenced to the North American Vertical Datum of 1988 (NAVD 88). 


\title{
Assessment of Water-Quality Data from Long Lake National Wildlife Refuge, North Dakota—2008 Through 2012
}

\author{
By Brian A. Tangen, ${ }^{1}$ Raymond G. Finocchiaro, ${ }^{1}$ Robert. A. Gleason, ${ }^{1}$ Michael J. Rabenberg, ${ }^{2}$ Charles F. Dahl, \\ and Michael J. Ell ${ }^{3}$
}

\section{Abstract}

Long Lake National Wildlife Refuge, located in southcentral North Dakota, is an important habitat for numerous migratory birds and waterfowl, including several threatened or endangered species. The refuge is distinguished by Long Lake, which is approximately 65 square kilometers and consists of four primary water management units. Water levels in the Long Lake units are maintained by low-level dikes and water-control structures, which after construction during the 1930s increased the water-storage capacity of Long Lake and reduced the frequency and volume of flushing flows downstream. The altered water regime, along with the negative precipitation:evaporation ratio of the region, may be contributing to the accumulation of water-borne chemical constituents such as salts, trace metals, and other constituents, which at certain threshold concentrations may impair aquatic plant, invertebrate, and bird communities of the refuge. The refuge's comprehensive conservation planning process identified the need for water-quality monitoring to assess current (2013) conditions, establish comparative baselines, evaluate changes over time (trends), and support adaptive management of the wetland units. In 2008, the U.S. Geological Survey, U.S. Fish and Wildlife Service, and North Dakota Department of Health began a water-quality monitoring program at Long Lake National Wildlife Refuge to address these needs. Biweekly water-quality samples were collected for ions, trace metals, and nutrients; and in situ sensors and data loggers were installed for the continuous measurement of specific conductance and water depth.

Long Lake was characterized primarily by sodium, bicarbonate, and sulfate ions. Overall results for total alkalinity and hardness were 580 and 329 milligrams per liter, respectively; thus, Long Lake is considered alkaline and classified as very hard. The mean $\mathrm{pH}$ and sodium adsorption ratio for Long Lake

${ }^{1}$ U.S. Geological Survey.

${ }^{2}$ U.S. Fish and Wildlife Service.

${ }^{3}$ North Dakota Department of Health. were 8.8 and 10 , respectively. Total dissolved solids concentrations averaged approximately 1,750 milligrams per liter, and ranged from 117 to 39,700 milligrams per liter. Twelve of the 14 trace metals detected in the water samples had established North Dakota water-quality standards for aquatic life, and only aluminum and copper consistently exceeded these criteria. Aluminum is considered harmful to aquatic biota in acidic ( $\mathrm{pH}$ less than 5.5) systems and most of the copper standard exceedances were collected from highly concentrated waters because of evaporation and seasonally low water levels. Concentrations for various forms of nitrogen and phosphorus generally were similar to reported regional values.

Specific conductance of Long Lake varied seasonally and annually both within and among management units, with values ranging from less than 500 to nearly 40,000 microsiemens per centimeter at 25 degrees Celsius. Long Lake was characterized by consistent seasonal patterns of increasing specific conductance from spring (March and April) to fall (September and October), with levels stabilizing through the end of the sampling season (November). These seasonal patterns in specific conductance were associated with decreasing water levels throughout the summer due primarily to evaporation and continuous water releases through the Unit 1 outlet structure, which resulted in the concentration of salts. Specific conductance of each unit, along with water levels, also varied among years. Overall, specific conductance levels were greatest during the drier year of 2008 when water levels were low. Specific conductance levels were lowest during the spring of 2009 following above-average volumes of fresh water from snowmelt runoff. Comparisons of specific conductance among sample sites that were spatially distributed within each management unit suggested that spatial variability within units was low except for areas associated with local inflows.

Data collected during this study revealed consistent seasonal patterns and low within-unit spatial variability of specific conductance. Based on these data results, future sample collection efforts may be reduced, as well as the number of sample locations, to limit sampling costs. Water-quality samples collected monthly or seasonally during the growing season (spring, summer, and fall) from a single representative 
location within each water-management unit should provide sufficient data to assess seasonal changes in water-quality over time and provide information for Long Lake management decisions.

\section{Introduction}

Long Lake National Wildlife Refuge (NWR) was established in 1932 and covers approximately 90 square kilometers $\left(\mathrm{km}^{2}\right)$ in south-central North Dakota (fig. 1). The refuge consists of a variety of wetland and grassland habitats, but is distinguished by Long Lake, an approximately $65-\mathrm{km}^{2}$ shallow alkaline lake consisting of four primary water management units (hereafter units): Unit 1, Unit 2, Unit 2 Marsh, and Unit 3. Units $1\left(7 \mathrm{~km}^{2}\right), 2\left(10 \mathrm{~km}^{2}\right)$, and $3\left(48 \mathrm{~km}^{2}\right)$ cover most of the refuge and were formed when Long Lake was modified by construction of three earthen dikes during the 1930s. The roughly $3-\mathrm{km}^{2}$ Unit 2 Marsh was created in 1995 when a dike was constructed across a bay on Unit 2 (fig. 2). The U.S. Fish and Wildlife Service (USFWS) currently (2013) manages the four units according to goals and objectives outlined in the refuge's Comprehensive Conservation Plan (CCP) (U.S. Fish and Wildlife Service, 2006). Detailed descriptions of Long Lake NWR are provided by the CCP (U.S. Fish and Wildlife Service, 2006) and Website (U.S. Fish and Wildlife Service, 2012), as well as by a biological assessment by Laubhan and others (2006).

The refuge is recognized as an important nesting habitat for migratory birds, particularly waterfowl, waterbirds, shorebirds, and grassland passerines (U.S. Fish and Wildlife Service, 2006). Three threatened or endangered birds nest on the refuge, including the piping plover (Charadrius melodus), snowy plover (Charadrius alexandrinus), and bald eagle (Haliaeetus leucocephalus). The endangered whooping crane (Grus americana) and large concentrations of sandhill cranes (Grus canadensis), Franklin's gulls (Larus pipixcan), greater white-fronted geese (Anser albifrons), and other birds use the refuge during migration. Peak populations of as much as 250,000 shorebirds gather during fall migration in years when shallow water and mudflats are abundant (U.S. Fish and Wildlife Service, 2006). Long Lake has a history of periodic, severe outbreaks of avian botulism (U.S. Fish and Wildlife Service, 2006). The dikes and control structures provide some water management capability, which has been partially effective for preventing or alleviating disease outbreaks.

It has been hypothesized that increasing the water-storage capacity and altering the frequency of flushing flows (flows capable of removing large quantities of water and water-borne chemical constituents from the refuge) of Long Lake through construction of the dikes and raising of the historic outlet elevation, in combination with greater water retention and a negative precipitation:evaporation ratio of approximately $0.4-0.48$ (U.S. Fish and Wildlife Service, 2006), are contributing to the accumulation of salts, trace metals, and other compounds that may negatively affect wetland-dependent biota (Laubhan and others, 2006; U.S. Fish and Wildlife Service, 2006). The increase in compounds likely has been exacerbated by longterm changes in land use, with the conversion of grassland to cropland resulting in greater precipitation runoff and contributions of sediments, nutrients, and agrichemicals from the surrounding watershed, including Long Lake Creek. Various trace metals and nutrients are detrimental to aquatic life when they exceed specific thresholds (U.S. Environmental Protection Agency, 1986; National Irrigation Water Quality Program, 1998), and the addition of dissolved salts or the concentration of existing salts or both can result in elevated salinity, which has been determined to negatively affect some waterfowl, plants, and invertebrates (for example, Stewart and Kantrud, 1972; Swanson and others, 1984; Hammer and Heseltine, 1988; Moorman and others, 1991; National Irrigation Water Quality Program, 1998; DeVink and others, 2005; Gleason and others, 2009).

Salt concentrations in prairie lakes can fluctuate over time because of changes in total salt mass associated with inflows, outflows, and deflation (loss of salts from dry lakebeds through wind). Processes such as evapoconcentration and dilution also can affect salt concentrations, though the total mass of salts remains unchanged (for example, Swanson and others, 1988; LaBaugh, 1989; LaBaugh and Swanson, 2003; Gleason and others, 2009; Tangen and others, 2013). Evapoconcentration is defined as the concentration of dissolved matter when water volume in a lake is reduced through evaporative processes. Of these processes, changes associated with concentration and dilution often are more pronounced than changes associated with the overall mass of salts, especially over shorter time scales (annual or decadal). Chemical characteristics also can vary spatially within a water body because of localized water inputs, groundwater interactions, and water exchange through water-control structures. Moreover, harmful effects to aquatic biota from elevated levels of various water-quality constituents can vary with the stage of the life cycle. For example, many plants are most sensitive to elevated salinity levels during germination, and young ducklings require freshwater because their salt glands take time to develop (Swanson and others, 1984; Baskin and Baskin, 1998). Therefore, to assess the water quality of a system in terms of habitat suitability for wildlife, one must characterize not only the overall water chemistry of a system (for example, annual average), but also assess the temporal and spatial variability to relate results to specific taxa or groups.

Long Lake generally is characterized by variable and often dynamic water-level changes driven primarily by spring snowmelt runoff, variable surface-water inflows, summer precipitation, and evapotranspiration. Therefore, understanding the natural temporal variation of the system in response to factors such as weather and water management will facilitate the development of goals and objectives. The USFWS has recognized the need for water-quality monitoring at Long Lake NWR to establish current (2013) baselines, evaluate temporal changes (trends), assess potential impacts to biotic 


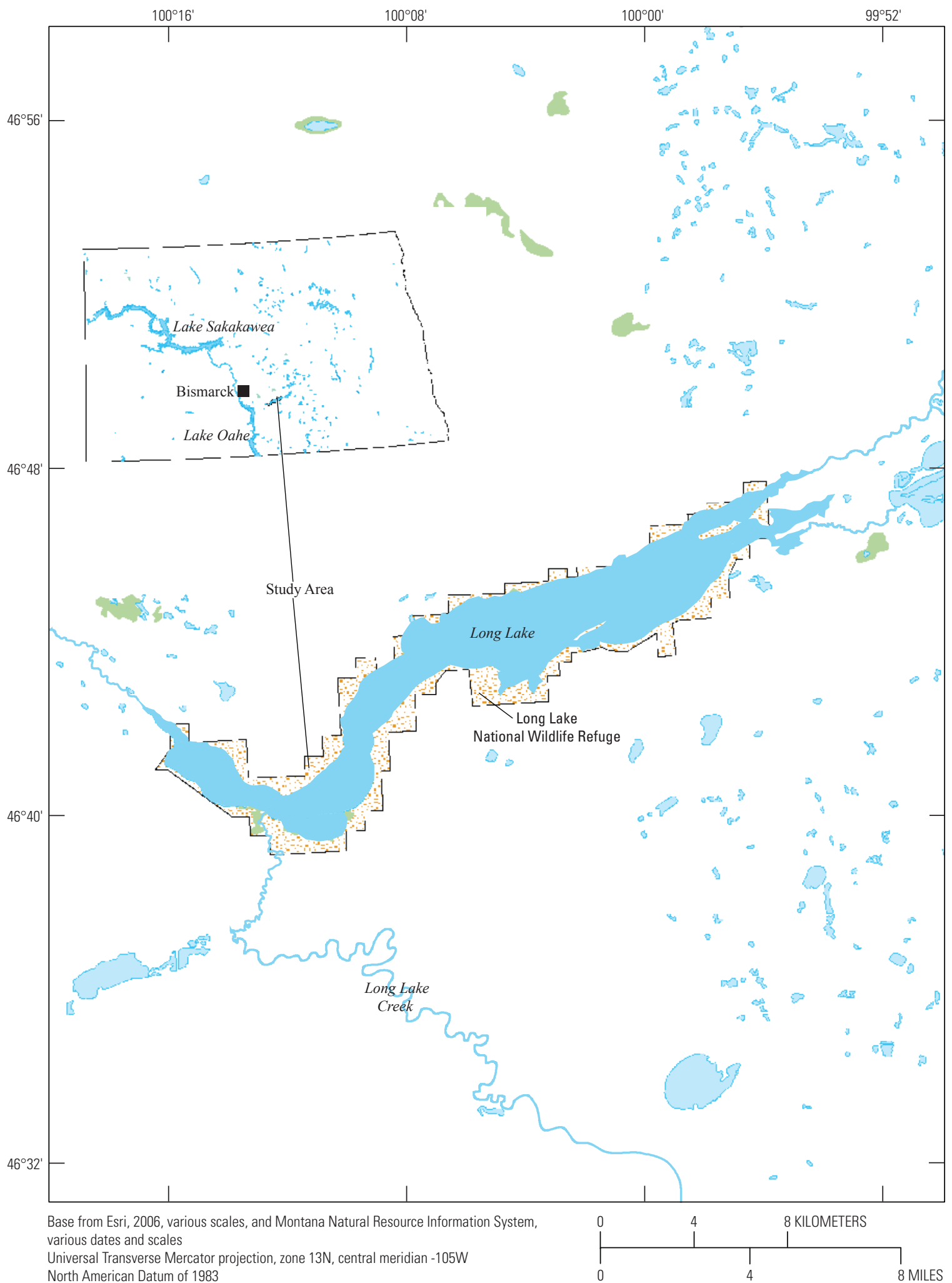

Figure 1. Location of Long Lake National Wildlife Refuge. 
communities, and support adaptive management of refuge wetlands (Laubhan and others, 2006; U.S. Fish and Wildlife Service, 2006). In 2008, the U.S. Geological Survey (USGS), USFWS, and North Dakota Department of Health (NDDH) began a water-quality monitoring effort in response to this need.

\section{Purpose and Scope}

The purpose of this report is to present and describe water-quality data collected from four water management units of Long Lake NWR from 2008 through 2012. Descriptions and interpretations of the data are meant to inform management decisions by the refuge and support evaluations of aquatic habitats. Water-quality data represent spatially distributed surface-water samples collected biweekly during the approximate ice-free season (mid-April to mid-November) from 12 to 19 sites, and 3 to 5 in situ sensors and data loggers.

\section{Study Area and Sample Sites}

The four primary units for Long lake NWR are separated by dikes with water-control structures that provided limited options for water-level management. Unit 1 is bordered by the A dike at the only outlet in the refuge, $\mathrm{B}$ dike separates Units 1 and 2, C dike separates Units 2 and 3, and Unit 2 Marsh dike

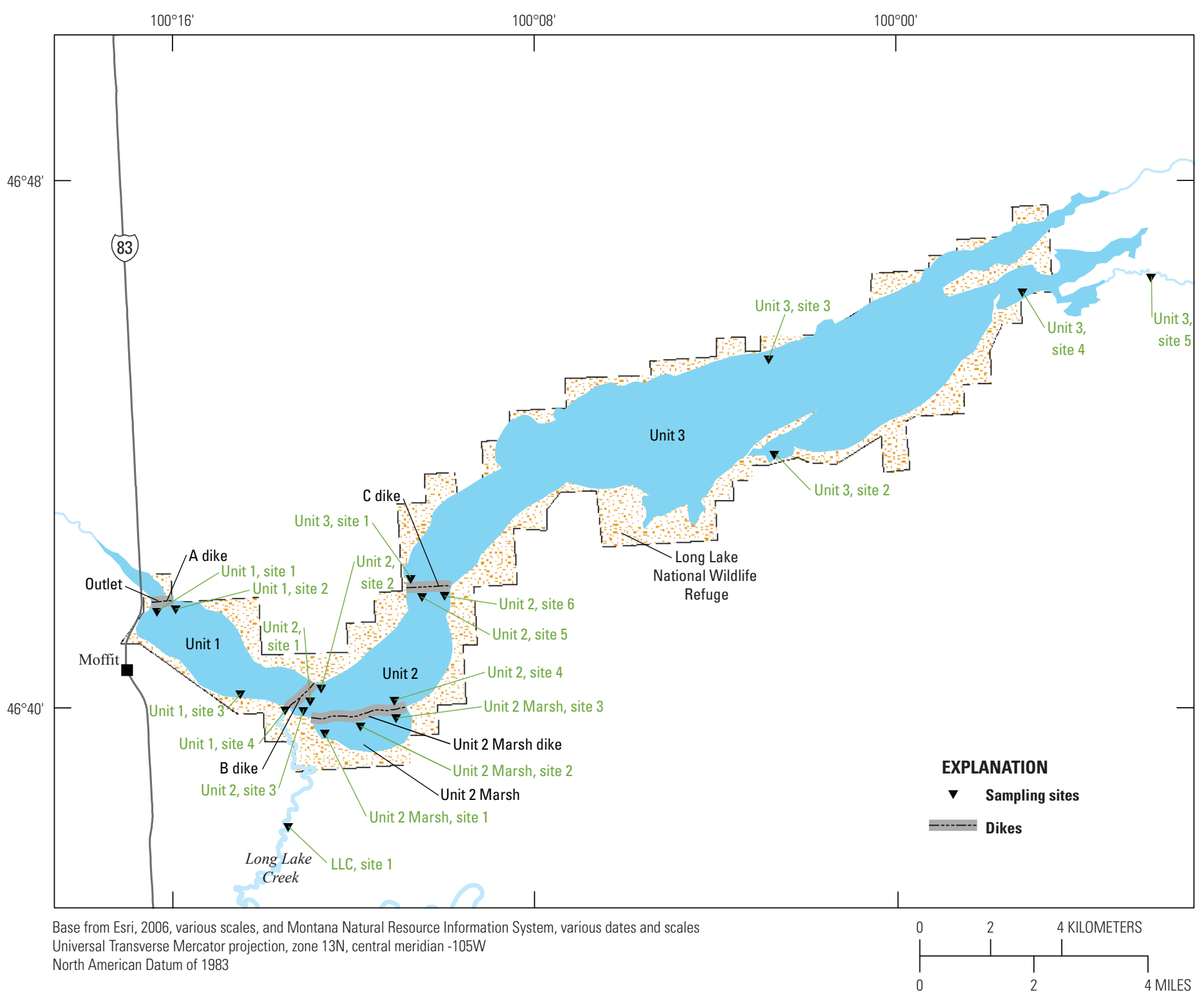

Figure 2. Locations of Long Lake National Wildlife Refuge water management units (Unit 1, Unit 2, Unit 2 Marsh, Unit 3), dikes (A dike, B dike, Unit 2 Marsh Dike, C dike), and study sample sites (see table 2). 
separates Unit 2 Marsh from Unit 2 (fig. 2). The A-dike outlet and the B-dike spillway are fixed-sill box culvert structures. The other water-control structures (B dike, C dike, Unit 2 Marsh dike) are adjustable stop-log structures. The limited ability to adjust water levels was further compromised when the $\mathrm{C}$-dike control structure between Unit 2 and Unit 3 was destroyed during a spring flood in 2009.

Most of the water for Long Lake is supplied by precipitation (including snowmelt runoff) and Long Lake Creek, which flows directly into the southeast part of Unit 1 near B Dike (figs. 1,2). Secondary inputs are received from numerous local tributaries and drainages surrounding the refuge. Long Lake is shallow (less than 2 meters), and Unit 2 Marsh and Unit 3 periodically become very shallow or dry. At the beginning of this study in July 2008, Unit 3 was dry and Unit 2 Marsh was extremely shallow (typically less than 5 centimeters water depth) with patches of dry land throughout; Units 1 and 2 had typical to below-average water levels of 1 to 2 meters deep. In fact, there were substantial deflation events during 2008 where salt plumes were observed from satellite imagery originating from Unit 3 and extending nearly to Canada (University of Wisconsin-Madison, 2013). These dry conditions followed below-average precipitation during 2006 and slightly aboveaverage precipitation during 2007 (fig. 3A). Mean annual temperatures during 2006 and 2007 were well above the longterm (1901-2000) average (fig. 3B). Runoff from an aboveaverage snowpack and early spring rains caused all units to rapidly exceed capacity in the spring of 2009. Unit 3 went from completely dry to flood stage in less than a week. Aboveaverage precipitation and below- to slightly above-average temperatures in 2009 through 2011 kept water levels high through most of 2012, when annual precipitation was below the long-term average and temperatures were greater than the previous 3 years (fig. 3 ).

All water-control structures were open (set to allow maximum flows) from April 2009 through 2012 to release excess water that was damaging and sometimes overtopping dikes and roads. Water flowed out of Long Lake through the Unit 1 outlet continuously from late March 2009 until August 2012. Flows out of Unit 1 are common in the spring, occurring every 2 to 3 years on average. The duration of these flows varies, and summer and fall outflows are rare. The recent multiyear (2009 through 2012) event may be unprecedented in the refuge's history. Using stage-discharge curves (described by Tangen and others, 2013) for Long Lake Creek and Unit 1, in conjunction with water-level data collected during this study, average inflows from Long Lake Creek and outflows from Unit 1 (at A dike) were estimated for the periods when sufficient data were available. Based on these estimates, average Long Lake Creek inflows exceeded outflows during 2008 through 2009, and outflows exceeded inflows from 2010 through 2012 (table 1). These estimates only provide for inflows associated with Long Lake Creek. Previous estimates suggest that other sources contribute approximately 32 percent of the water to Long Lake (U.S. Fish and Wildlife Service, 2006).
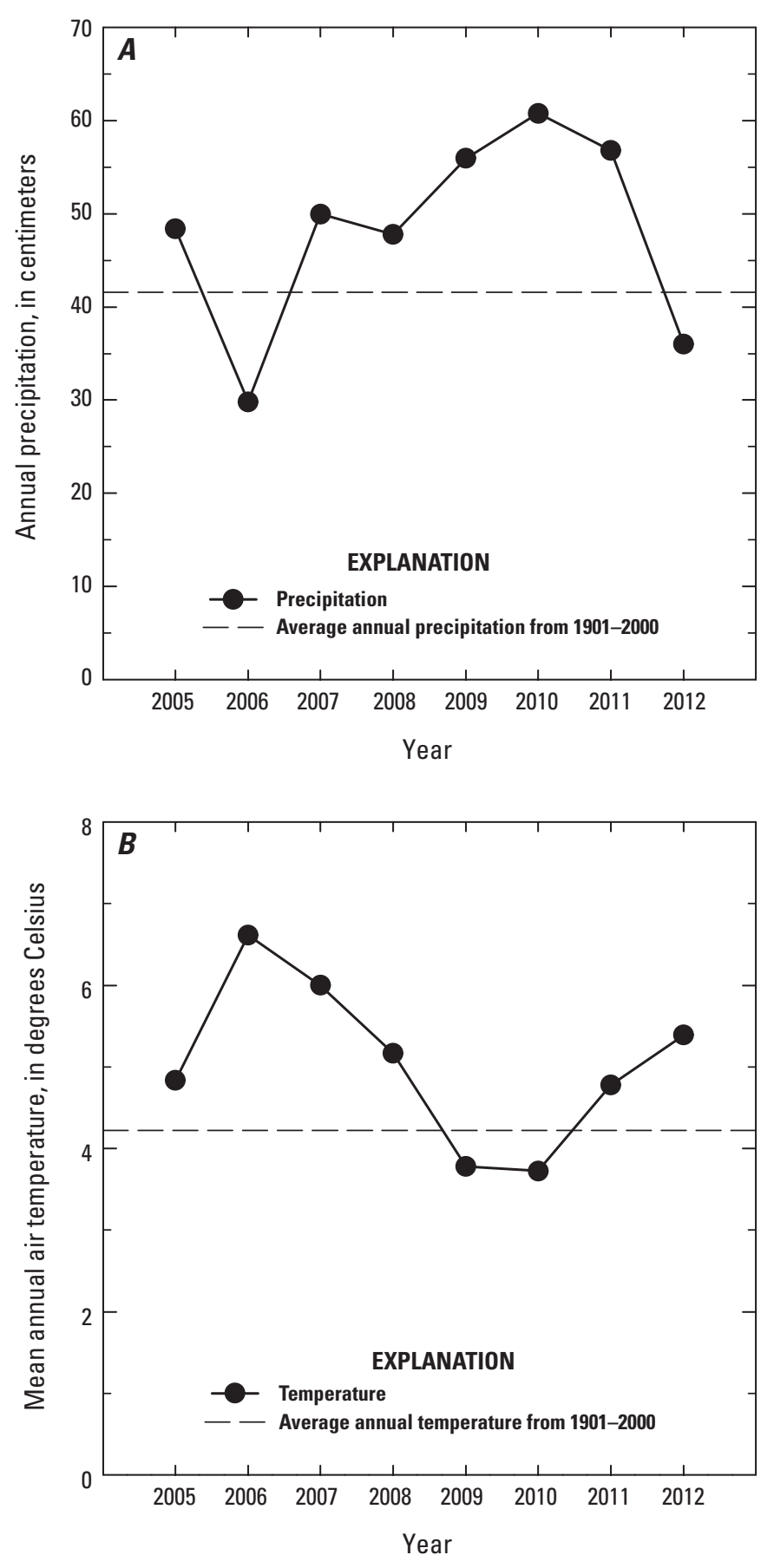

Figure 3. $A$, Total annual precipitation for south-central North Dakota, and $B$, mean annual air temperature for south-central North Dakota. Data were obtained from the National Climatic Data Center for North Dakota climate division 8 (National Oceanic and Atmospheric Administration, 2013). 
Because of the large size of Long Lake, and the differences among water sources, spatial variation in water-quality characteristics may exist; thus, sample sites were distributed throughout the Lake to determine spatial variation (fig. 2). In 2008, 12 water sampling sites were established. One site (LLC, site 1) was located upstream (south) from the refuge on Long Lake Creek near a discontinued USGS streamgage (gage 06349215 above Long Lake near Moffit, North Dakota), four sites were located on Unit 1 and Unit 2, and three sites were established in Unit 2 Marsh (fig. 2; table 2). Before sampling in 2009, two sites were added to Unit 2 and four sites were established in Unit 3. A fifth site (Unit 3, site 5) was added to a tributary east of Unit 3 during 2012 to assess inflows associated with a recent drainage project connecting a neighboring watershed to the Long Lake watershed. Unit 3, site 5 is located about 1.5 kilometers upstream from the mouth of the tributary. A drainage ditch was constructed to remove flood waters from Alkali Lake in southeast Kidder County, and

Table 1. Estimated mean inflow from Long Lake Creek and outflow from Long Lake during 2008 through 2012.

[Difference was calculated as average outflow minus average inflow. Flows were estimated using measured water elevations and stage-discharge curves. $\mathrm{ft}^{3} / \mathrm{s}$, cubic feet per second]

\begin{tabular}{|c|c|c|c|c|c|}
\hline Year & Date range & Number of records & $\begin{array}{c}\text { Inflow, } \\
\mathrm{ft}^{3} / \mathrm{s}\end{array}$ & $\begin{array}{c}\text { Outflow, } \\
\mathrm{ft}^{3} / \mathrm{s}\end{array}$ & $\begin{array}{c}\text { Difference, } \\
\mathrm{ft}^{3} / \mathrm{s}\end{array}$ \\
\hline 2008 & June 19-October 17 & 107 & 8.48 & 0.00 & -8.48 \\
\hline 2010 & April 23-November 19 & 211 & 59.91 & 94.42 & 34.51 \\
\hline 2011 & May 11-October 26 & 169 & 143.72 & 193.63 & 49.91 \\
\hline
\end{tabular}

Table 2. Range of sample dates, number of sample sites, sample site number, and number of biweekly water-quality samples collected at Long Lake from 2008 through 2012.

[The number of biweekly sample periods varies because some sites were established later in the year than others, some sites dried seasonally, or sites were not accessible during specific time periods. Additionally, during 2010-11 Long Lake Creek was sampled more frequently in conjunction with a related study. --, no data]

\begin{tabular}{|c|c|c|c|c|c|c|c|c|c|}
\hline \multirow[b]{2}{*}{ Year } & \multicolumn{2}{|c|}{ Date } & \multirow{2}{*}{$\begin{array}{l}\text { Number } \\
\text { of sites }\end{array}$} & \multicolumn{5}{|c|}{ Site number } & \multirow{2}{*}{$\begin{array}{c}\text { Number of } \\
\text { sample periods }\end{array}$} \\
\hline & Start & End & & $\begin{array}{l}\text { Long Lake } \\
\text { Creek }\end{array}$ & Unit 1 & Unit 2 & $\begin{array}{l}\text { Unit } 2 \\
\text { Marsh }\end{array}$ & Unit 3 & \\
\hline 2009 & April 2 & November 17 & 18 & 1 & $1,2,3,4$ & $1,2,3,4,5,6$ & $1,2,3$ & $1,2,3,4$ & $12-15$ \\
\hline 2010 & Mar 23 & November 18 & 18 & 1 & $1,2,3,4$ & $1,2,3,4,5,6$ & $1,2,3$ & $1,2,3,4$ & $15-25$ \\
\hline
\end{tabular}

${ }^{1}$ No samples were collected from Unit 3 during 2008 because it was dry.

Table 3. Ranges of dates that in situ sensors and data loggers were installed at Long Lake, 2008 through 2012.

$[--$, no data $]$

\begin{tabular}{ccccccc}
\hline Year & $\begin{array}{c}\text { Long Lake Creek, } \\
\text { site 1 }\end{array}$ & $\begin{array}{c}\text { Unit 1, } \\
\text { site 1 }\end{array}$ & $\begin{array}{c}\text { Unit 2, } \\
\text { site 2 }\end{array}$ & $\begin{array}{c}\text { Unit 2, } \\
\text { site 5/6 }\end{array}$ & $\begin{array}{c}\text { Unit 2 Marsh, } \\
\text { site 3 }\end{array}$ & $\begin{array}{c}\text { Unit 3, } \\
\text { site 1 }\end{array}$ \\
\hline 2008 & May 13-Nov. 14 & June 19-Oct. 17 & -- & May 14-Nov. 8 & -- \\
2009 & June 18-Nov. 18 & Apr. 23-Nov. 18 & Apr. 23-Nov. 18 & Apr. 23-Nov. 18 & - -- \\
2010 & Apr. 23-Nov. 19 & Apr. 22-Nov. 19 & Apr. 22-Nov. 18 & Apr. 22-Nov. 19 & Aug. 16-Nov. 10 & Apr. 23-Nov. 19 \\
2011 & May 11-Oct. 26 & May 11-Oct. 26 & May 11-Oct. 26 & May 11-Oct. 26 & May 11-Oct. 26 & May 11-Oct. 26 \\
2012 & Apr. 4-Nov. 13 & Apr. 4-Nov. 13 & Apr. 4-Nov. 13 & Apr. 4-Nov. 13 & Apr. 4-Nov. 13 & Apr. 4-Nov. 13 \\
\hline
\end{tabular}


this water moves through numerous wetlands before discharging into the northeast part of Unit 3. In addition, in situ automated sensors were installed in Long Lake Creek, Unit 1, Unit 2, Unit 2 Marsh, and Unit 3 (fig. 2; table 3).

\section{Methods}

\section{Water-Quality Samples}

Water samples were collected biweekly (twice a month) during the approximate ice-free season each year (table 2) for determination of ions, trace metals, and nutrients, as well as various water-quality properties such as $\mathrm{pH}$, alkalinity, hardness, total dissolved solids, specific conductance, and sodium adsorption ratio (SAR) (table 4). Surface grab samples using a long-handled dipper were collected according to the NDDH standard methods for wadeable wetlands (North Dakota Department of Health, 2012a). Samples for nutrient assays were preserved with sulfuric acid and samples for the remaining water-quality constituents were preserved with nitric acid; all samples were unfiltered. All laboratory analyses were completed by the NDDH Laboratory Services Division according to analytical methods outlined in the Chemistry Laboratory Quality Assurance Program, January 2013 Revision (North Dakota Department of Health, 2013). Field measurements for specific conductance and temperature were measured during each biweekly sample event using a YSI EC300 ${ }^{\mathrm{TM}}$ hand-held meter (YSI Inc., Yellow Springs, Ohio).

\section{In Situ Sensors}

Continuous measurements of specific conductance, water depth, and water temperature were collected during the ice-free season using conductivity and temperature sensors, pressure transducers, and data loggers. Locations of the equipment and time periods of installation are presented in table 3. From 2008 through 2010, a CS547A (Campbell Scientific Inc., Logan, Utah) conductivity and temperature sensor and a series 500 SDI-12 (Campbell Scientific Inc., Logan, Utah) submersible pressure transducer were used in conjunction with a CR10 (Campbell Scientific Inc., Logan, Utah) data logger. In 2010, LTC Levelogger Juniors (Solinst Canada LTD., Georgetown, Ontario) equipped with a pressure transducer and conductivity and temperature sensors were installed alongside the existing sensors and transducers. The stand-alone Levelogger Juniors

Table 4. Reporting criteria for water-quality characteristics, properties, and constituents analyzed in water samples collected from Long Lake.

$\left[<\right.$, less than; $\mu \mathrm{g} / \mathrm{L}$, micrograms per liter; $\mathrm{mg} / \mathrm{L}$, milligrams per liter; $\mathrm{Ca}^{2+}$, calcium; $\mathrm{Mg}^{2+}$, magnesium; $\mathrm{Na}^{+}$, sodium; $\mathrm{CaCO}_{3}$, calcium carbonate; --, no data; $\mu \mathrm{S} / \mathrm{cm}$ at $25^{\circ} \mathrm{C}$, microsiemens per centimeter at 25 degrees Celsius]

\begin{tabular}{|c|c|c|c|c|c|c|c|c|}
\hline \multicolumn{3}{|c|}{ Trace metals } & \multicolumn{3}{|c|}{ Ions and salinity } & \multicolumn{3}{|c|}{ Nutrients } \\
\hline Element & $\begin{array}{c}\text { Detec- } \\
\text { tion } \\
\text { limit }\end{array}$ & Unit & Ion/variable & $\begin{array}{c}\text { Detection } \\
\text { limit }\end{array}$ & Unit & Nutrient & $\begin{array}{c}\text { Detection } \\
\text { limit }\end{array}$ & Unit \\
\hline Aluminum & $<50$ & $\mu \mathrm{g} / \mathrm{L}$ & Bicarbonate & $<1$ & $\mathrm{mg} / \mathrm{L}$ & Ammonia (nitrogen) & $<0.03$ & $\mathrm{mg} / \mathrm{L}$ \\
\hline Antimony & $<1$ & $\mu \mathrm{g} / \mathrm{L}$ & $\mathrm{Ca}^{2+}$ & $<2$ & $\mathrm{mg} / \mathrm{L}$ & Nitrate plus nitrite & $<0.03$ & $\mathrm{mg} / \mathrm{L}$ \\
\hline Arsenic & $<1$ & $\mu \mathrm{g} / \mathrm{L}$ & Carbonate & $<1$ & $\mathrm{mg} / \mathrm{L}$ & Nitrogen (total) & $<0.015$ & $\mathrm{mg} / \mathrm{L}$ \\
\hline Beryllium ${ }^{1}$ & $<1$ & $\mu \mathrm{g} / \mathrm{L}$ & Hydroxide $^{1}$ & $<1$ & $\mathrm{mg} / \mathrm{L}$ & Phosphorus (total) & $<0.004$ & $\mathrm{mg} / \mathrm{L}$ \\
\hline Boron & $<50$ & $\mu \mathrm{g} / \mathrm{L}$ & $\mathrm{Mg}^{2+}$ & $<1$ & $\mathrm{mg} / \mathrm{L}$ & & & \\
\hline Cadmium $^{1}$ & $<1$ & $\mu \mathrm{g} / \mathrm{L}$ & Potassium & $<1$ & $\mathrm{mg} / \mathrm{L}$ & & & \\
\hline Chromium & $<1$ & $\mu \mathrm{g} / \mathrm{L}$ & $\mathrm{Na}^{+}$ & $<3$ & $\mathrm{mg} / \mathrm{L}$ & & & \\
\hline Copper & $<1$ & $\mu \mathrm{g} / \mathrm{L}$ & Sulfate & $<0.3$ & $\mathrm{mg} / \mathrm{L}$ & & & \\
\hline Nickel & $<1$ & $\mu \mathrm{g} / \mathrm{L}$ & Specific conductance & $<4$ & $\mu \mathrm{S} / \mathrm{cm}$ at $25^{\circ} \mathrm{C}$ & & & \\
\hline Selenium & $<1$ & $\mu \mathrm{g} / \mathrm{L}$ & Total dissolved solids & -- & $\mathrm{mg} / \mathrm{L}$ & & & \\
\hline Silver & $<1$ & $\mu \mathrm{g} / \mathrm{L}$ & $\mathrm{pH}$ & -- & standard units & & & \\
\hline Thallium $^{1}$ & $<1$ & $\mu \mathrm{g} / \mathrm{L}$ & & & & & & \\
\hline Zinc & $<1$ & $\mu \mathrm{g} / \mathrm{L}$ & & & & & & \\
\hline
\end{tabular}

${ }^{1}$ Not detected in any samples.

${ }^{2}$ Calculated as $\left[\mathrm{Na}^{+}\right] /\left\{\left[\mathrm{Ca}^{2+}+\mathrm{Mg}^{2+}\right] / 2\right\}^{1 / 2}$. 
were used exclusively starting in 2011. All sensors were calibrated according to manufacturer specifications before installation. Water depth at each sample site was converted to pool elevation (hereafter water level) using data from a GPS survey system and nearby known-elevation survey benchmarks and staff gages.

\section{Data Descriptions and Comparisons}

\section{Ions, Trace Metals, and Nutrients}

Descriptive statistics and graphical summaries are used to present the data from the water-quality samples and in situ sensors. Water-quality properties were compared to North Dakota water-quality standards (North Dakota Department of Health, 2012b) to determine if any of them regularly exceed established criteria developed to protect aquatic biota. State water-quality standards are expressed as acute or chronic values intended to protect aquatic biota and as values intended to protect human health. An acute standard is defined as a 1-hour average concentration that is not exceeded more than once every 3 years, and a chronic standard is defined as a 4-day average concentration that is not exceeded more than once every 3 years. Maximum values are defined in the standards of quality for waters of the State of North Dakota (North Dakota Department of Health, 2012b) for specific applications such as irrigation or drinking water. Water-quality criteria are developed by the U.S. Environmental Protection Agency (USEPA) through determination of the effects of pollutants on human and environmental health (U.S. Environmental Protection Agency, 1986; U.S. Environmental Protection Agency, 2000b). Because the purpose of this monitoring effort is to evaluate habitats for aquatic life, the acute and chronic standards for aquatic life are the primary focus hereafter.

Nutrient concentrations can be highly variable, and concentrations for a given water body are dependent on site-specific factors; thus, region-wide standards often are not available. The State of North Dakota is currently (2013) developing nutrient criteria and does have acute and chronic standards (temperature and $\mathrm{pH}$ dependent) for ammonia (North Dakota Department of Health, 2012b). The USEPA also provides regional reference values for some nutrients (U.S. Environmental Protection Agency, 2000a); therefore, data from Long Lake were compared to the ammonia standards and to the guideline values for nutrients to qualitatively assess nutrient loads and concentrations.

\section{Temporal Patterns and Spatial Variability}

Specific conductance was used as a representative property to identify and assess temporal and spatial variability in water quality. Seasonal and interannual patterns in specific conductance and water levels are described and depicted graphically using data from the in situ sensors and biweekly water-quality samples. These data also were used to examine spatial patterns among the four units and Long Lake Creek. Variability within each unit was assessed by examining plots of specific conductance from the water-quality data. Specific conductance was used to assess temporal and spatial patterns because it is correlated with salt and dissolved matter concentrations and generally reflects the changes in the concentration of other chemical constituents (Swanson and others, 1988). Further, specific conductance is a measure of salinity and is an important variable to consider when assessing habitat quality because it can affect plant and invertebrate communities that provide critical food and structural resources for many migratory and wetland-dependent birds (Laubhan and others, 2006; Gleason and others, 2009). Specific conductance generally displays a positive correlation with dissolved matter and a negative correlation with water levels (Eisenlohr and others, 1972; Swanson and others, 1988; Laubhan and others, 2006; Tangen and others, 2013). Specific conductance in semiclosedbasin lakes and wetlands can be affected by changes in the overall salt balance, or it also can fluctuate in conjunction with changes in water volumes associated with evaporation, inflows, and precipitation.

\section{Concentrations of Chemical Constituents}

\section{Ions}

The four units of Long Lake NWR and Long Lake Creek were characterized by three major ions: sodium, bicarbonate, and sulfate. Minor cations and anions were magnesium, calcium, potassium, carbonate, and chloride (fig. 4; table 5). The ionic makeup of Long Lake is characteristic of lakes and wetlands in the area and generally reflects the geologic setting (Eisenlohr and others, 1972; Swanson and others, 1988). Of the major and minor ions, North Dakota has established water-quality standards for chloride and sulfate (table 6; North Dakota Department of Health, 2012b). Chloride exceeded the standard in less than 3 percent of samples, and all of these samples were collected from Unit 2 Marsh during low waterlevel conditions. Sulfate exceeded the standard in greater than 90 percent of samples (table 6), but values were similar to those reported for other lakes in the area, which often are characterized by sulfate waters (Swanson and others, 1988). Further, the water-quality standard for chloride and sulfate are secondary drinking water standards; thus, they are not directly relevant to Long Lake, which is primarily used to support wildlife.

Specific conductance and total dissolved solids averaged approximately 2,400 (range 204-38,700) microsiemens per centimeter at 25 degrees Celsius $\left(\mu \mathrm{S} / \mathrm{cm}\right.$ at $\left.25^{\circ} \mathrm{C}\right)$ and 1,750 (range 117-39,700) milligrams per liter $(\mathrm{mg} / \mathrm{L})$, respectively. Long Lake is alkaline, with a mean total alkalinity of approximately $580 \mathrm{mg} / \mathrm{L}$. The system is characterized by a mean $\mathrm{pH}$ of 8.8, and a mean total hardness of $329 \mathrm{mg} / \mathrm{L}$, resulting 
in a classification of very hard (Briggs and Ficke, 1977; Omernick and others, 1988). The mean SAR was 10, and is less than 12, the general value considered detrimental to soils and plants (U.S. Salinity Laboratory Staff, 1954; Gleason and others, 2009). Summary statistics for waterquality constituents are presented for Long Lake in table 5. Data from all water samples ( 37 variables per sample; see table 4), including Long Lake Creek, are presented by sample site and date in appendix 1. Specific conductance and water temperature measured with the hand-held meter are presented in appendix 2.

\section{Trace Metals}

Summary statistics for the detected trace metals are presented in table 7. Twelve of the 14 detected trace metals have established North Dakota water-quality standards for acute, chronic, maximum, or human health (table 6; North Dakota Department of Health, 2012b). Most trace metals only exceeded the aquatic life standards (acute, chronic) in a small number of samples that usually were associated with low water levels. Aluminum exceeded the acute and chronic standards in greater than 70 and 100 percent of samples, respectively (fig. 5; table 6). Copper exceeded the acute and chronic standards for approximately 6 and 20 percent of samples, respectively (fig. 6, table 6). Arsenic and boron exceeded the human health and maximum standards in more than 80 percent of samples. Arsenic exceeded the aquatic life standards in less than 2 percent of samples. These percentages are based on individual (daily) samples, and not on the 1-hour (acute) or 4-day (chronic) averages used to develop the standards. Nonetheless, these comparisons provide overall assessments of trace metals in Long Lake.

Aluminum in surface water is complex and some forms of aluminum may be more toxic than others. Aluminum is largely insoluble in waters with a $\mathrm{pH}$ of $6-8$, and is generally considered toxic to aquatic biota only in acidic (pH less than 5.5) systems (Hem, 1985; Sparling and others, 1996; U.S. Environmental Protection Agency, 1988; Gensemer and Playle, 1999; Wetzel, 2001; Schwarz and others, 2004). The chronic standard for aluminum typically is not applied to waters where the $\mathrm{pH}$ is greater than 7.0 and hardness is greater than $50 \mathrm{mg} / \mathrm{L}$. Although concentrations of aluminum consistently exceeded the acute standards for all Long Lake units, the observed concentrations were characterized by a mean $\mathrm{pH}$ of 8.8 and hardness of $329 \mathrm{mg} / \mathrm{L}$ (table 5). Aluminum concentrations from Long Lake Creek were lower than aluminum concentrations from Long Lake NWR units (fig. 5). Aluminum may be transported to Long Lake with suspended sediments because it readily binds to clays and can be associated with surface-water runoff (Hem, 1985; U.S. Environmental Protection Agency, 1988; Gensemer and Playle, 1999; Wetzel, 2001). Although the maximum aluminum concentration was $77,200 \mathrm{mg} / \mathrm{L}$ in
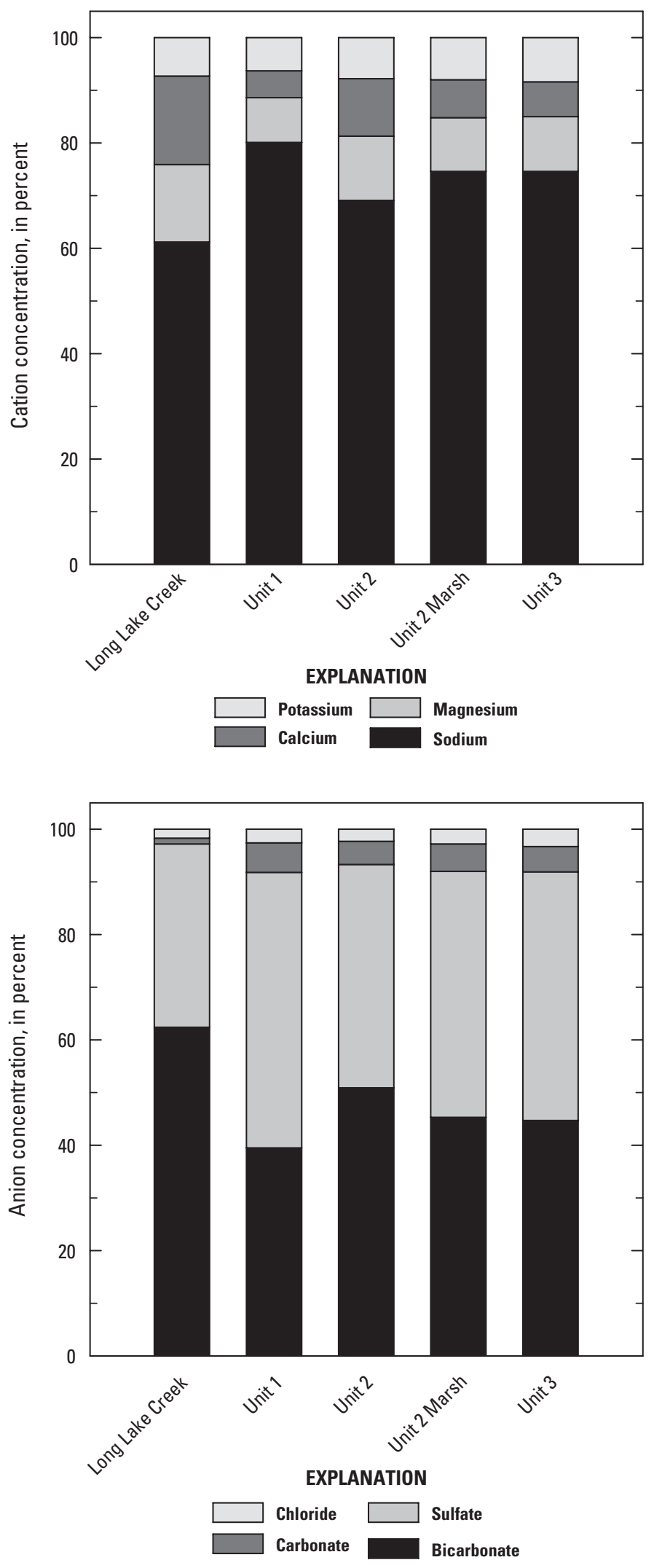

Figure 4. Mean concentrations of cations and anions from water-quality samples of Long Lake Creek and Unit 1, Unit 2, Unit 2 Marsh, and Unit 3 of Long Lake National Wildlife Refuge, 2008 through 2012. 
Table 5. Summary statistics for ions and water-quality constituents for water samples collected from Long Lake, 2008 through 2012. $\left[\mathrm{mg} / \mathrm{L}\right.$, milligrams per liter; <, less than; $\mu \mathrm{S} / \mathrm{cm}$ at $25^{\circ} \mathrm{C}$, microsiemens per centimeter at 25 degrees Celsius; TDS, total dissolved solids; SAR, sodium adsorption ratio; $\mathrm{CaCO}_{3}$, calcium carbonate]

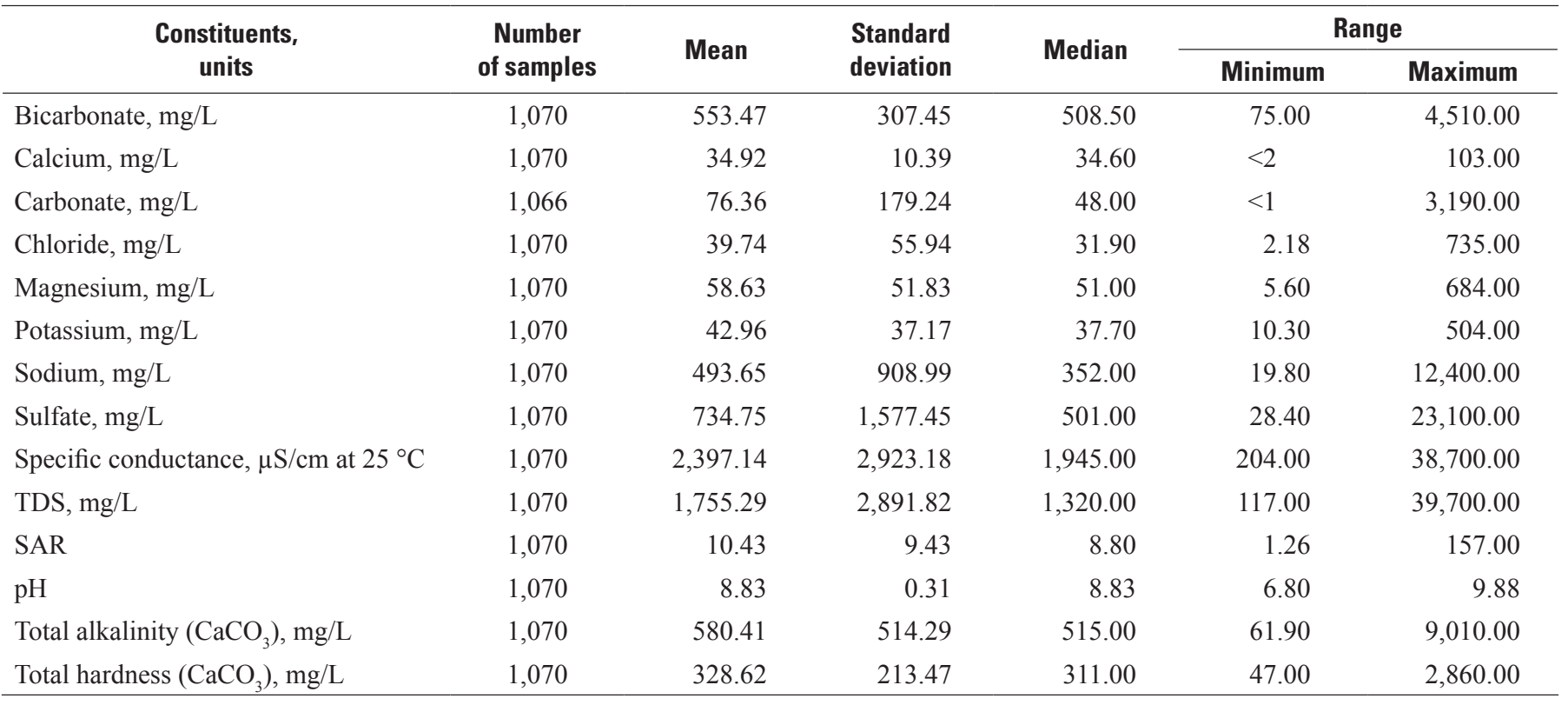

Table 6. North Dakota water-quality criteria for ions, trace metals, and nutrients, and the percent of exceedances for water samples from Long Lake, 2008 through 2012. Standards are outlined in the standards of quality for waters of the State (North Dakota Department of Health, 2012b).

[mg/L, milligrams per liter; --, no data; $\mu \mathrm{g} / \mathrm{L}$, micrograms per liter]

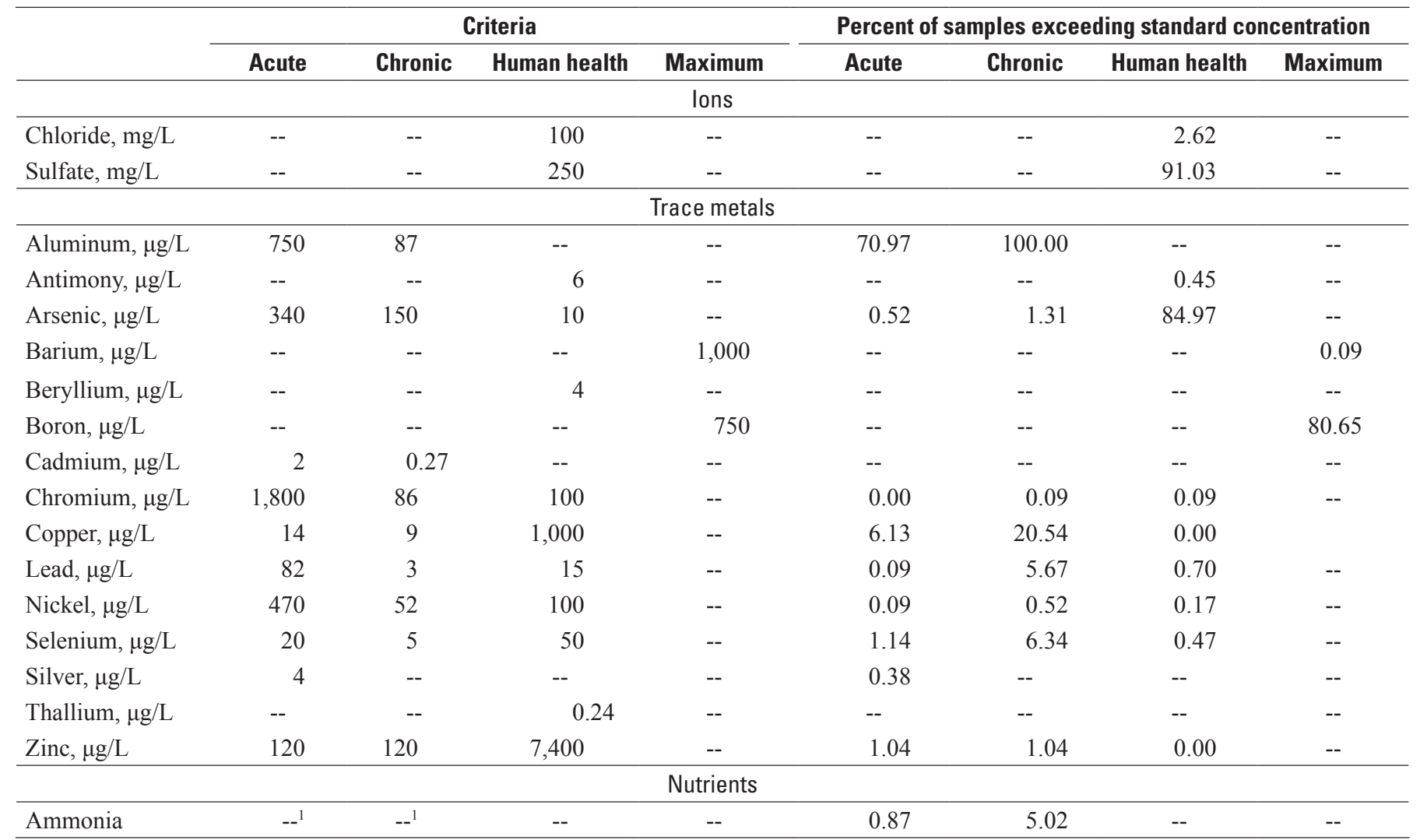

${ }^{1}$ Criteria are $\mathrm{pH}$ and temperature dependent. See standards of quality for waters of the State (North Dakota Department of Health, 2012b) for formulas. 


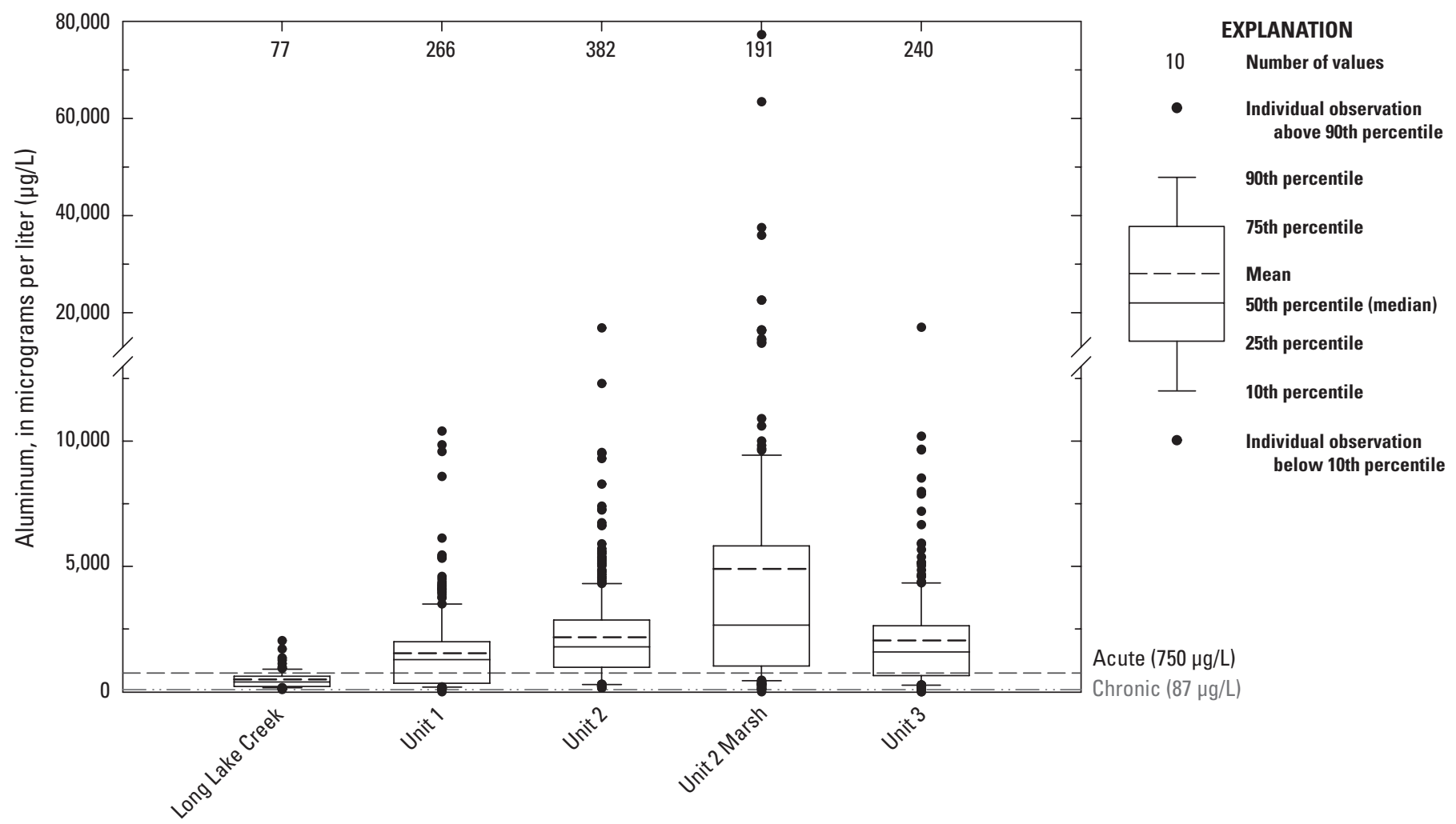

Figure 5. Aluminum concentrations from water-quality samples of Long Lake Creek and Unit 1, Unit 2, Unit 2 Marsh, and Unit 3 of Long Lake National Wildlife Refuge, 2008 through 2012, in relation to acute and chronic standard values.

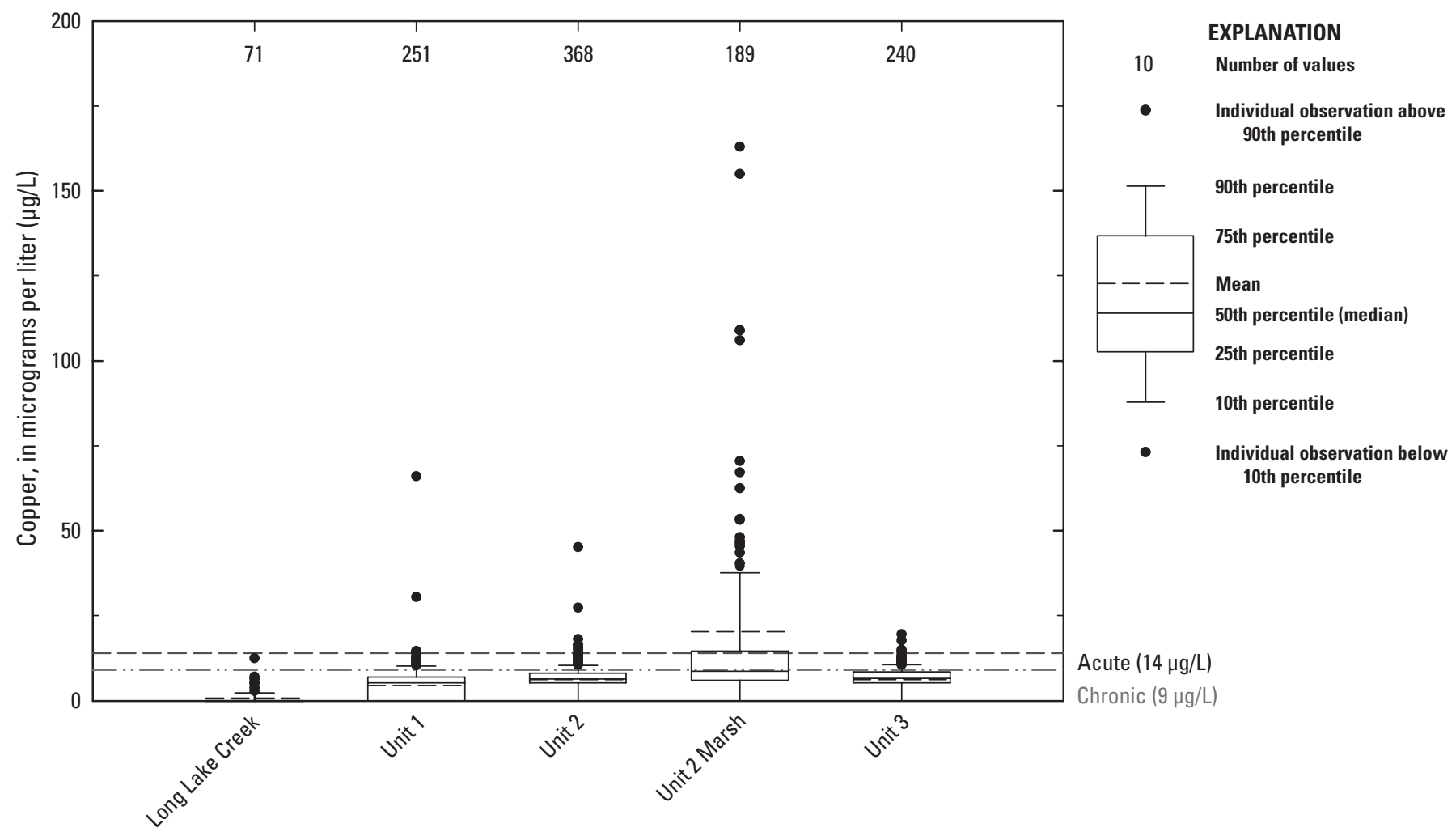

Figure 6. Copper concentrations from water-quality samples of Long Lake Creek and Unit 1, Unit 2, Unit 2 Marsh, and Unit 3 of Long Lake National Wildlife Refuge, 2008 through 2012, in relation to acute and chronic standard values. 
Long Lake (table 7), the mean aluminum concentration generally was similar to previous data collected by the NDDH for North Dakota lakes and to surface waters in the region that ranged from 10 to $657,000 \mu \mathrm{g} / \mathrm{L}$ (Schwarz and others, 2004; Ryberg and Hiemenz, 2009; Galloway and others, 2012).

Copper, much like aluminum, is adsorbed to organic and clay particles that can be transported into Long Lake with inflows. The solubility of copper decreases as $\mathrm{pH}$ and aluminum activity increase (Tisdale and Nelson, 1975) and copper may accumulate in sediments of lakes with high $\mathrm{pH}$ and aluminum activity. Under reducing (low oxygen) conditions, however, copper may be released into solution (McLaren and Crawford, 1973). Most of the copper samples from Unit 2 Marsh exceeded the acute and chronic standards and often were associated with low water levels. Most of the copper samples from the other Long Lake units had concentrations that were within reported values for freshwater systems (for example, Schwarz and others, 2004; U.S. Environmental Protection Agency, 2007; Ryberg and Hiemenz, 2009). However, comparisons of copper with source waters from Long Lake Creek indicate a pattern similar to aluminum that may be accumulating over time in the Long Lake units (fig. 6).

\section{Nutrients}

Summary statistics for nutrients (nitrogen and phosphorus) are presented in table 8. The State of North Dakota's acute and chronic standards (North Dakota Department of Health, $2012 b$ ) for ammonia were exceeded for approximately 1 and 5 percent of samples, respectively (table 6). Overall average concentrations of total nitrogen, nitrate + nitrite, total phosphorus, and total-Kjeldahl nitrogen generally corresponded to regional reference values for lakes and reservoirs (U.S. Environmental Protection Agency, 2000a), as well as reported

Table 7. Summary statistics for trace metals collected from Long Lake, 2008 through 2012.

[ $\mu \mathrm{g} / \mathrm{L}$, micrograms per liter; $<$, less than; $\mathrm{mg} / \mathrm{L}$, milligrams per liter]

\begin{tabular}{lrrrrrr}
\hline Trace metals, & Numits & Number & Mean & Standard & Median & \multicolumn{2}{c}{ Range } \\
\cline { 6 - 7 } deviation & & & Minimum & Maximum \\
\hline Aluminum, $\mu \mathrm{g} / \mathrm{L}$ & 1,070 & $2,496.34$ & $4,132.50$ & $1,660.00$ & $<50$ & $77,200.00$ \\
Antimony, $\mu \mathrm{g} / \mathrm{L}$ & 985 & 0.07 & 0.94 & 0.00 & $<1$ & 22.40 \\
Arsenic, $\mu \mathrm{g} / \mathrm{L}$ & 1,069 & 29.96 & 59.61 & 21.80 & $<1$ & $1,570.00$ \\
Barium, $\mu \mathrm{g} / \mathrm{L}$ & 1,069 & 87.40 & 128.87 & 78.30 & $<1$ & $4,120.00$ \\
Boron, $\mu \mathrm{g} / \mathrm{L}$ & 1,070 & $1,590.37$ & $1,963.70$ & $1,300.00$ & $<50$ & $26,400.00$ \\
Chromium, $\mu \mathrm{g} / \mathrm{L}$ & 1,002 & 2.71 & 28.61 & 0.00 & $<1$ & 893.00 \\
Copper, $\mu \mathrm{g} / \mathrm{L}$ & 1,039 & 8.38 & 32.31 & 6.45 & $<1$ & 983.00 \\
Iron, $\mathrm{mg} / \mathrm{L}$ & 1,070 & 3.20 & 4.58 & 2.18 & 0.14 & 84.00 \\
Lead, $\mu \mathrm{g} / \mathrm{L}$ & 989 & 1.04 & 14.17 & 0.00 & $<1$ & 438.00 \\
Manganese, $\mathrm{mg} / \mathrm{L}$ & 1,070 & 0.19 & 0.21 & 0.13 & 0.02 & 3.14 \\
Nickel, $\mu \mathrm{g} / \mathrm{L}$ & 1,036 & 8.65 & 29.11 & 6.71 & $<1$ & 906.00 \\
Selenium, $\mu \mathrm{g} / \mathrm{L}$ & 1,003 & 1.17 & 9.55 & 0.00 & $<1$ & 233.00 \\
Silver, $\mu \mathrm{g} / \mathrm{L}$ & 983 & 0.04 & 0.64 & 0.00 & $<1$ & 12.40 \\
Zinc, $\mu \mathrm{g} / \mathrm{L}$ & 1,050 & 20.30 & 80.13 & 13.40 & $<1$ & $2,510.00$ \\
\hline
\end{tabular}

Table 8. Summary statistics for nutrients from water samples collected from Long Lake, 2008 through 2012.

$[\mathrm{mg} / \mathrm{L}$, milligrams per liter; $<$, less than]

\begin{tabular}{|c|c|c|c|c|c|c|}
\hline \multirow{2}{*}{ Chemical characteristic } & \multirow{2}{*}{$\begin{array}{c}\text { Number } \\
\text { of samples }\end{array}$} & \multirow{2}{*}{ Average } & \multirow{2}{*}{$\begin{array}{l}\text { Standard } \\
\text { deviation }\end{array}$} & \multirow{2}{*}{ Median } & \multicolumn{2}{|c|}{ Range } \\
\hline & & & & & Minimum & Maximum \\
\hline Total nitrogen, mg/L & 1,070 & 2.54 & 3.99 & 1.67 & 0.07 & 57.30 \\
\hline Nitrate + nitrite, $\mathrm{mg} / \mathrm{L}$ & 1,041 & 0.16 & 0.32 & 0.06 & $<0.03$ & 6.59 \\
\hline Total phosphorus, mg/L & 1,070 & 0.67 & 0.35 & 0.65 & 0.01 & 4.17 \\
\hline
\end{tabular}


values for various aquatic systems (Schwarz and others, 2004; Ryberg and Hiemenz, 2009; Galloway and others, 2012). However, maximum concentrations of some nutrients (total nitrogen, total phosphorus, total-Kjeldahl nitrogen) often exceeded these reference and reported values. Most of these largest values were from Unit 2 Marsh and likely may be associated with evapotranspiration and concentration. The retention and subsequent evapoconcentration of local surface inflows or groundwater by the Unit 2 Marsh Dike may contribute to the higher readings. A further study would be required to assess these factors.

\section{Temporal Patterns}

During the study, the four units of Long Lake NWR were characterized by consistent seasonal patterns of increasing specific conductance from spring (March/April) to fall (September/October), with levels then stabilizing through the end of the sampling season (November) (fig. 7). Minor seasonal fluctuations in specific conductance were evident for Long Lake Creek, but overall values were relatively constant compared to the Long Lake units (fig. 7). These seasonal patterns in specific conductance were associated with decreasing water levels throughout the summer primarily because of evapotranspiration, which resulted in the increased concentration of salts (figs. 8-12). Continuous releases of water from Long Lake at the Unit 1 outlet for most of the study (table 1) also contributed to the water-level declines, especially during 2010-11. There were several reductions in specific conductance that correlated with increased water levels (dilution) because of water inputs from substantial precipitation and runoff events or inflows from Long Lake Creek. Similarly, specific conductance levels often stabilized during the fall, due in part to reduced evaporative and transpirative losses.

Specific conductance of each unit, along with water levels, also varied among years (figs. 7-12). Overall, specific conductance levels were greatest during the drier year of 2008 (excluding Unit 3, which was completely dry) when water levels were low. In general, specific conductance levels were lowest in the spring of 2009 following above-average volumes of fresh water from snowmelt runoff (fig. 7).

Specific conductance values for Long Lake Creek remained relatively stable throughout the study when compared to the Long Lake units, despite seasonal changes in water levels (fig. 8). However, these consistent observed levels are expected for a flowing water system where salts are not greatly concentrated through evaporative processes.

Overall, specific conductance values for Long Lake Creek ranged from approximately 700 to $1,800 \mu \mathrm{S} / \mathrm{cm}$ at $25^{\circ} \mathrm{C}$. Specific conductance of Unit 1 increased seasonally in conjunction with declining water levels from 2008 through 2011, and varied during 2012 (fig. 9). Specific conductance of Unit 1 ranged from approximately 500 to $3,000 \mu \mathrm{S} /$ $\mathrm{cm}$ at $25^{\circ} \mathrm{C}$ and water levels ranged from about 1,715 to
1,719 feet. The lack of a typical seasonal pattern during 2012 is likely because of reduced inflows from Long Lake Creek and reduced outflows from Unit 1 that ceased (water levels fell below fixed-sill water-control structure) in about August 2012 (table 1). The inflows may have partially mitigated the concentration effects associated with evaporation once outflows ceased. Specific conductance of Units 2 and 3 increased seasonally in conjunction with declining water levels during all years (concentration effect). There were, however, some short-term decreases in specific conductance associated with increased water levels and dilution of salts (figs. 10, 12). Specific conductance of Units 2 and 3 ranged from approximately 500 to $3,500 \mu \mathrm{S} / \mathrm{cm}$ at $25^{\circ} \mathrm{C}$, with water levels ranging from about 1,715 to $1,718.5$ feet.

Unit 2 Marsh indicated seasonal patterns of increasing specific conductance with declining water levels during most years (water level data only available for 2010-12; fig. 11). There were noticeable reductions in specific conductance during the fall of 2008 and 2012 that were likely associated with precipitation. During the high-water years of 2009-12, specific conductance of Unit 2 Marsh ranged from approximately 1,000 to $6,000 \mu \mathrm{S} / \mathrm{cm}$ at $25^{\circ} \mathrm{C}$ and water levels ranged from about 1,715 to 1,719 feet; however, during the extremely dry year of 2008 values ranged from approximately 10,000 to $35,000 \mu \mathrm{S} / \mathrm{cm}$ at $25^{\circ} \mathrm{C}$.

Specific conductance levels for all units varied during the 5 years of this study. Ranges reported for this study are similar to available historic data, although historic water level information required to make more informed comparisons was not sufficient. Specific conductance values for Unit 1 reported for this study were generally less than $2,000 \mu \mathrm{S} / \mathrm{cm}$ at $25^{\circ} \mathrm{C}$, except for the dry year of 2008 when values approached $3,000 \mu \mathrm{S} / \mathrm{cm}$ at $25^{\circ} \mathrm{C}$ (fig. 9). Historic values for Unit 1, collected during 1988 and 2004, ranged from 1,220 to $3,220 \mu \mathrm{S} / \mathrm{cm}$ at $25^{\circ} \mathrm{C}$ (Olson and Welsh, 1991; Laubhan and others, 2006). Values for Units 2 and 3 reported for this study were generally less than $3,000 \mu \mathrm{S} / \mathrm{cm}$ at $25^{\circ} \mathrm{C}$, with values for Unit 2 approaching $3,500 \mu \mathrm{S} / \mathrm{cm}$ at $25^{\circ} \mathrm{C}$ during 2008 (figs. 10, 12). Historic values for Unit 2, collected during 1988 and 2004 , ranged from 2,600 to $2,800 \mu \mathrm{S} / \mathrm{cm}$ at $25^{\circ} \mathrm{C}$ (Olson and Welsh, 1991; Laubhan and others, 2006), and a value of 7,300 $\mu \mathrm{S} / \mathrm{cm}$ at $25^{\circ} \mathrm{C}$ was reported during January 1989 , when salts were presumably concentrated under ice (Olson and Welsh, 1991). Historic values for Unit 3, collected during 1969, 1988, and 2004, ranged from 4,000 to 4,200 (Swanson and others, 1988; Olson and Welsh, 1991; Laubhan and others, 2006), and an estimated value of $8,886 \mu \mathrm{S} / \mathrm{cm}$ at $25^{\circ} \mathrm{C}$ was reported during January, 1989 (Olson and Welsh, 1991). Historic values for Unit 2 Marsh were unavailable.

Comparisons and assessments of seasonal patterns in specific conductance were difficult because the historic data were limited (Swanson and others, 1988; Olson and Welsh, 1991; Laubhan and others, 2006). In general, comparisons of current (2008 through 2012) specific conductance suggest that Units 1 and 2 are within a typical range since about 1988. Specific conductance levels of Unit 3 from this study are below values 


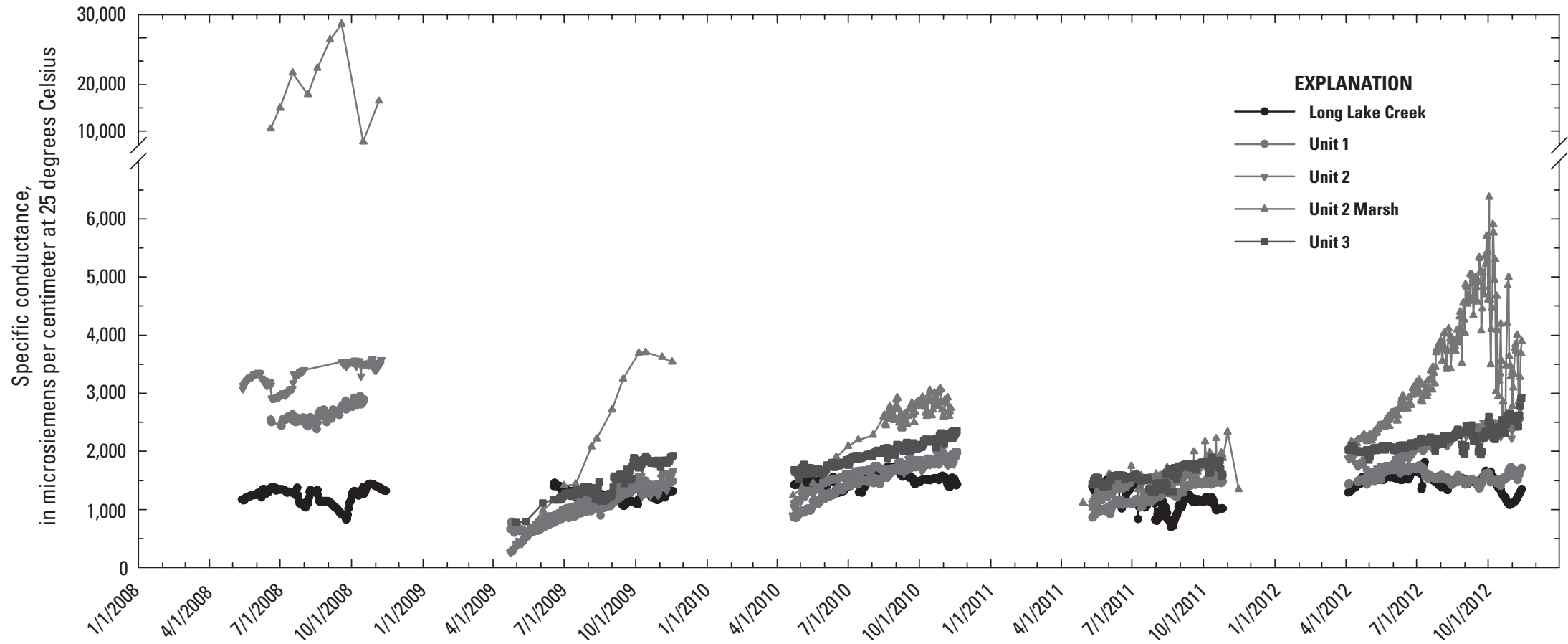

Figure 7. Specific conductance from in situ sensors located at Long Lake Creek and Unit 1, Unit 2, Unit 2 Marsh, and Unit 3 of Long Lake National Wildlife Refuge, 2008 through 2012. 


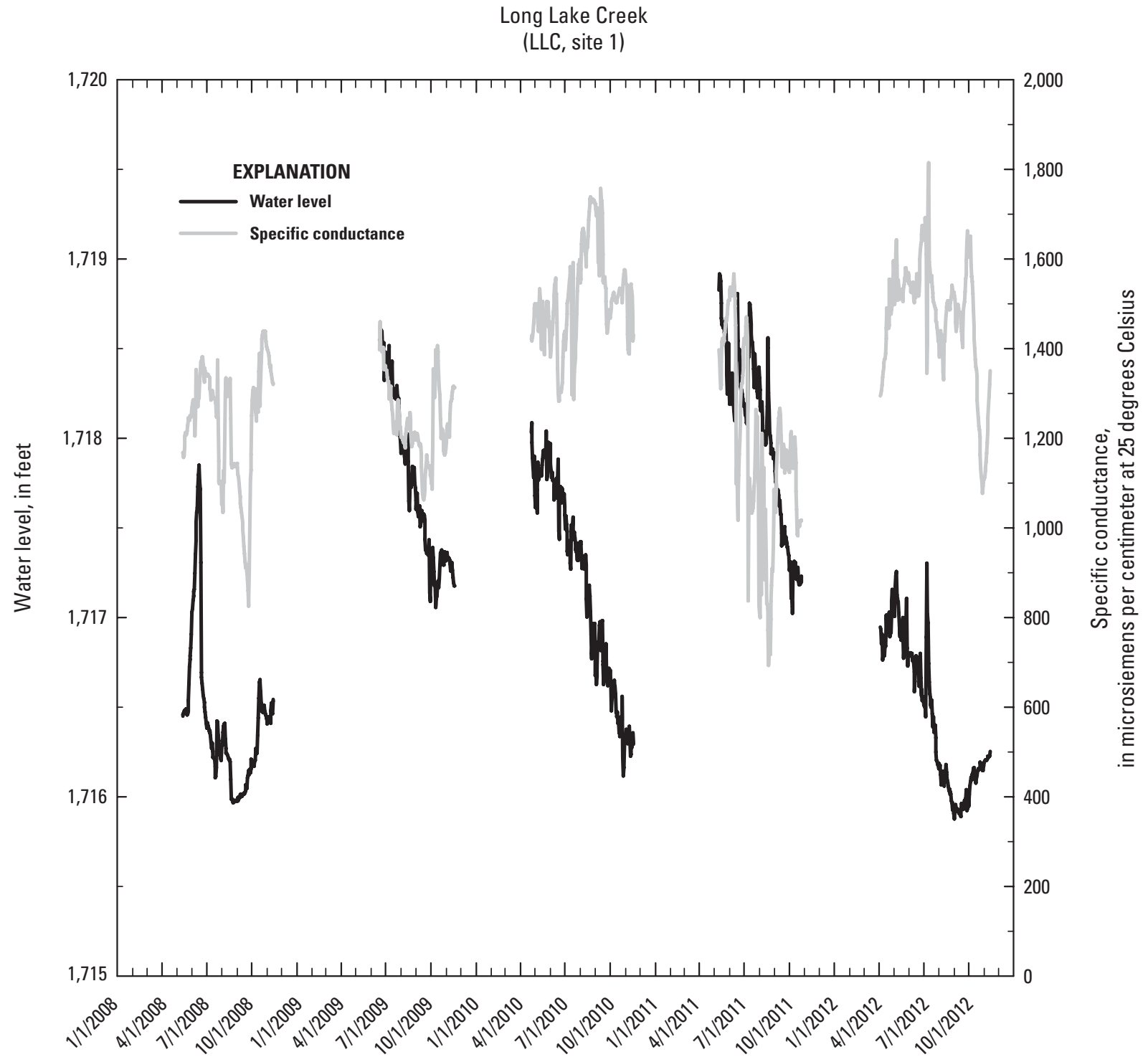

Figure 8. Water level and specific conductance for Long Lake Creek upstream of Long Lake National Wildlife Refuge, 2008 through 2012.

reported since 1969, and these current (2008 through 2012) low values are likely because of dilution effects associated with the high observed water levels since 2009. Additionally, a large but unknown quantity of salts was removed from Unit 3 through deflation during 2008 (University of WisconsinMadison, 2013), and this loss of salts also may have contributed to the lower observed values during this study. There is a possibility that, before drying in 2008 , specific conductance levels of Unit 3 may have exceeded the 1994 reported value of $4,200 \mu \mathrm{S} / \mathrm{cm}$ at $25^{\circ} \mathrm{C}$ because of highly concentrated salts associated with above-average temperatures (greater evaporation) and below-average precipitation in 2006 (fig. 3). 
Unit 1

(Unit 1, site 1)

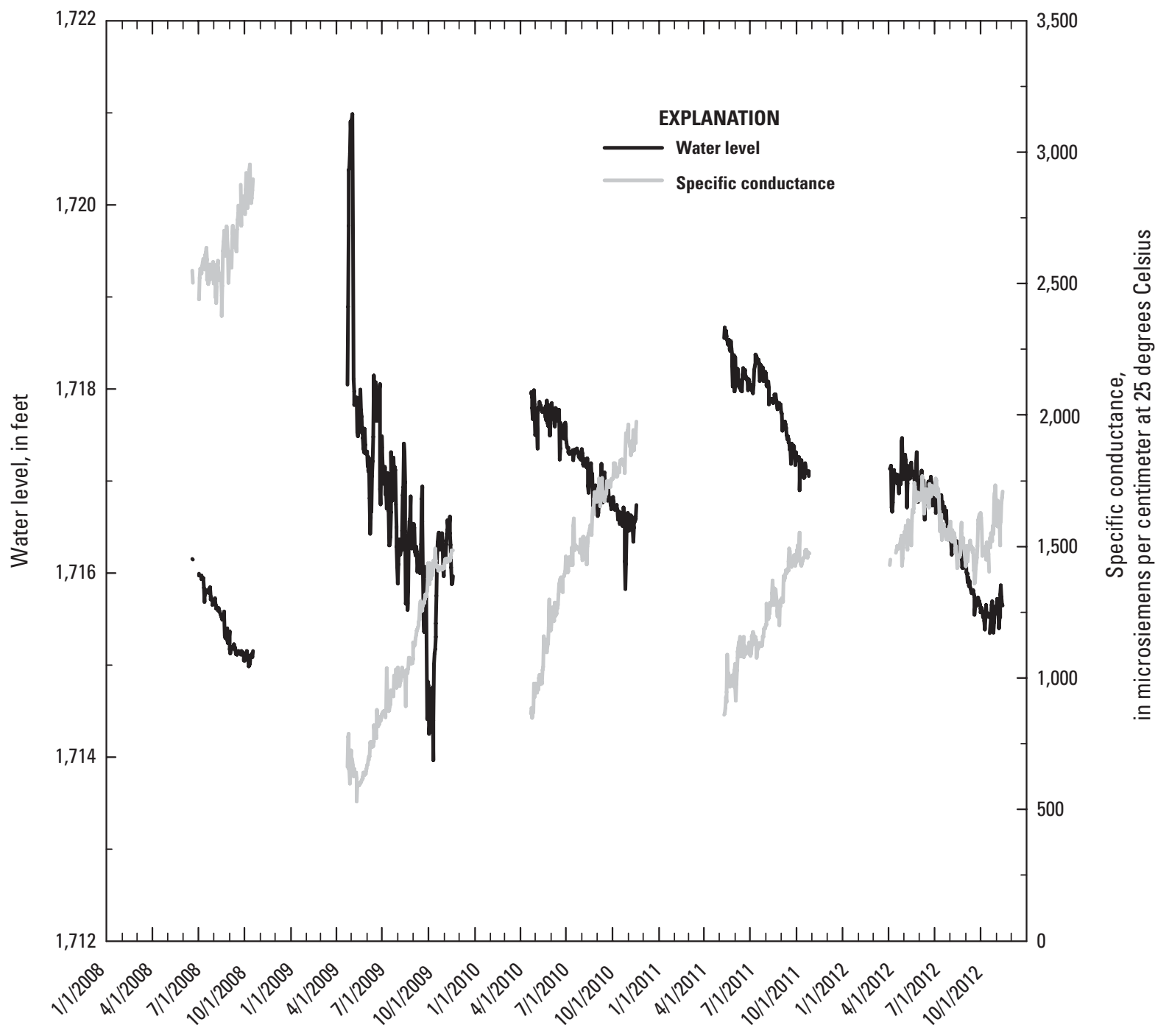

Figure 9. Water level and specific conductance for Unit 1 of Long Lake National Wildlife Refuge, 2008 through 2012. 
Unit 2

(Unit 2, sites 2/5/6)

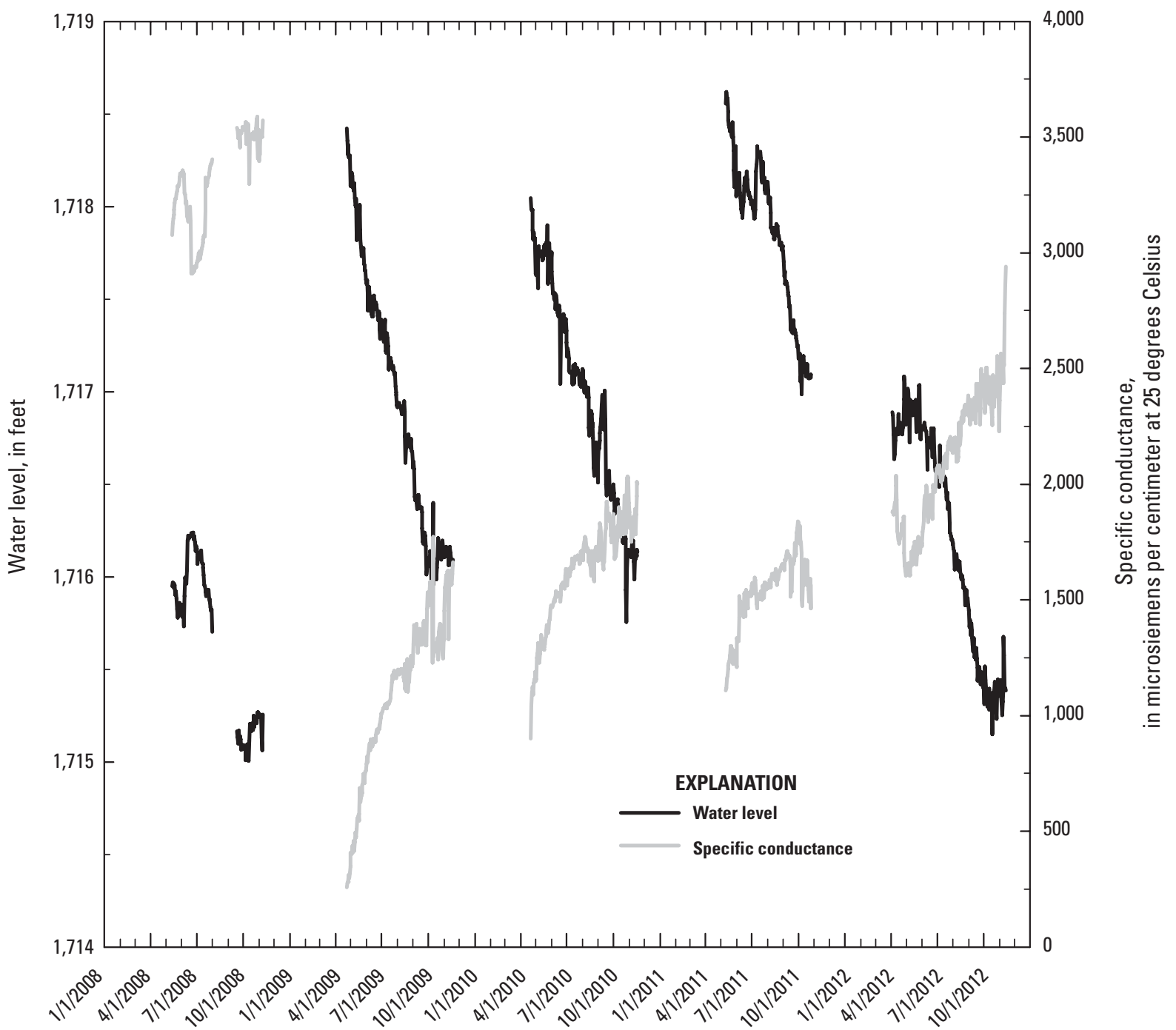

Figure 10. Water level and specific conductance for Unit 2 of Long Lake National Wildlife Refuge, 2008 through 2012. 


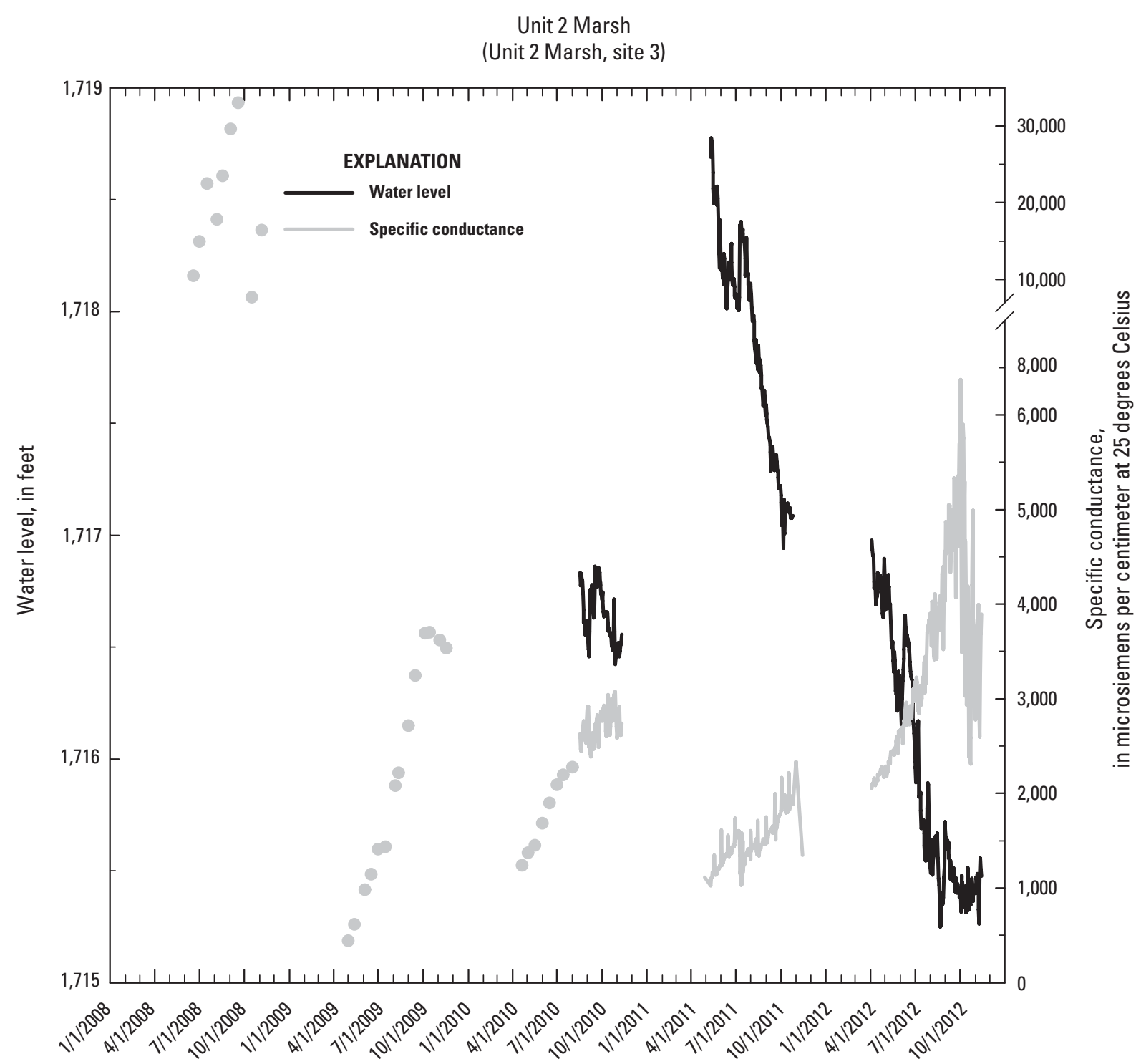

Figure 11. Water level and specific conductance for Unit 2 Marsh of Long Lake National Wildlife Refuge, 2008 through 2012. Water level data only available from 2010 through 2012. 
Unit 3

(Unit 3, site 1)

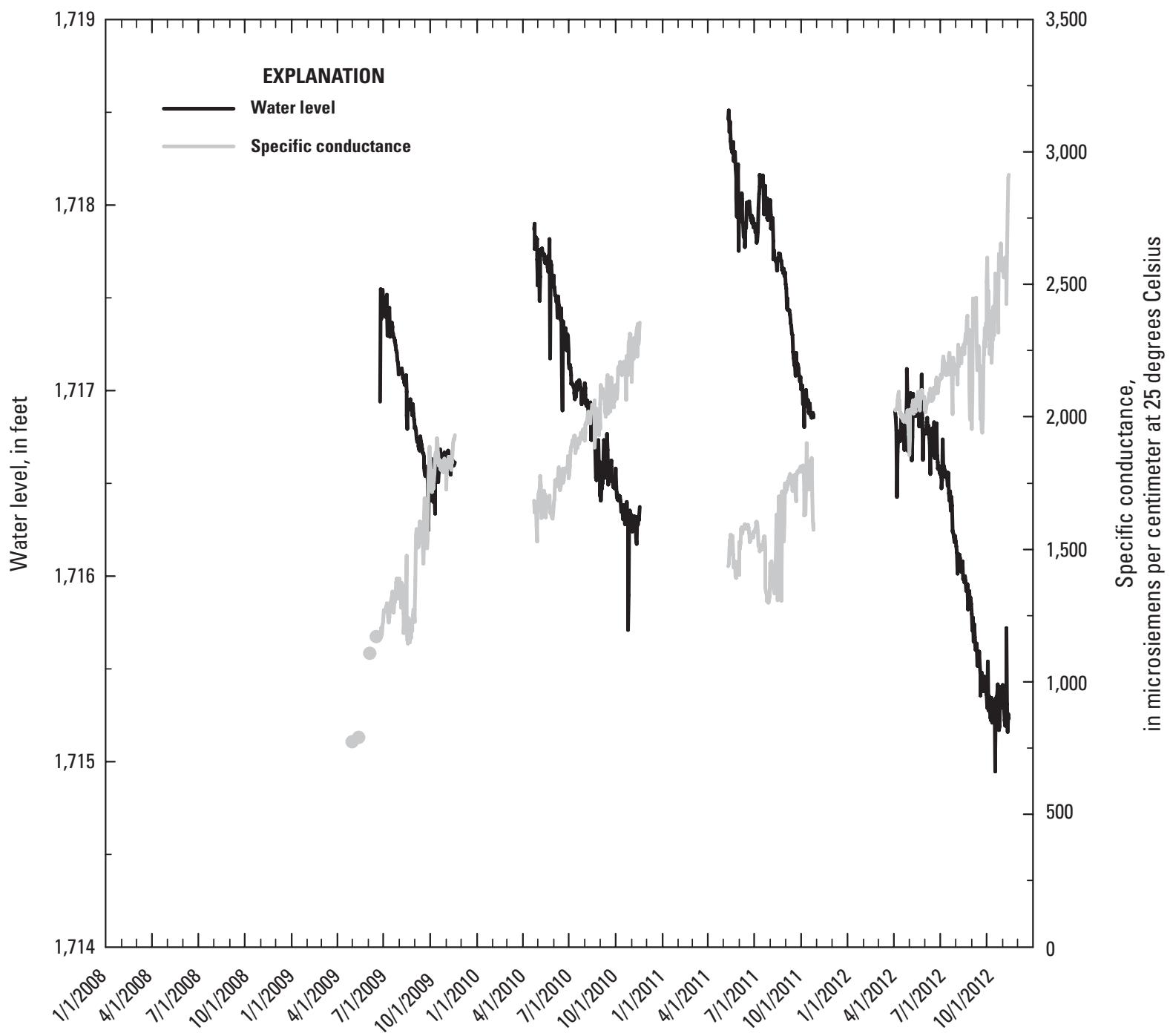

Figure 12. Water level and specific conductance for Unit 3 of Long Lake National Wildlife Refuge, 2008 through 2012. Unit 3 was dry during 2008. 


\section{Among-Unit Variability}

A spatial pattern of increasing specific conductance was evident along a concentration gradient from southwest (Unit 1) to northeast (Unit 3) in the refuge (figs. 2, 7). The Long Lake units are not a typical flow-through series of impoundments in that both the primary water source (Long Lake Creek) and the system outlet are both in Unit 1 . Water entering Unit 1 is pushed into Units 2 and 3 during high flow periods where it can be stored by closing the control structures in B dike and $\mathrm{C}$ dike. The primary water source for Unit 2 Marsh during average years is Unit 2; contributions from overbank flooding of Long Lake Creek can be substantial during flood years. As you move northeast ("uphill") where the units are separated by dikes, the effects of evapoconcentration are more pronounced because of a lack of consistent inflows when compared to Unit 1, and to a lesser extent Unit 2 (which mixes more frequently with Unit 1). This pattern of increasing specific conductance was most pronounced during the extremely dry year of 2008 when water levels were extremely low and Unit 3 went completely dry. Patterns were more subtle from 2009 through 2012 (fig. 7) when all units had been diluted by large volumes of fresh water during 2009 and there was inter-unit mixing through the water-control structures. Unit 2 Marsh consistently displayed greater specific conductance levels than the other units except in 2011 when water levels were highest (greatest dilution of salts) and specific conductance was similar to the other units (fig. 7). Further, the Unit 2 Marsh dike was breached during 2009 and overtopped following spring runoff in 2009, 2010, and 2011, resulting in some mixing with Unit 2. The Unit 2 Marsh dike was partially repaired during 2012.

\section{Within-Unit Variability}

Specific conductance from the biweekly water-quality samples are presented by management unit, sample site, and sample periods in figures 13-16. Overall, within-unit specific conductance variation among sample sites appeared to be consistent between data points. Specific conductance for each sample period was similar among Unit 1, sites 1-3; however, data for Unit 1, site 4, where Long Lake Creek enters Unit 1, was consistently distinguished from the other three sites (fig. 13). Specific conductance of Unit 1, site 4 was constant within and among years, and levels were lower than the other sites when specific conductance was greatest during 2008 and 2012. These patterns are not unexpected because Unit 1, site 4 was located at the mouth of Long Lake Creek where it discharges into Unit 1; thus, the patterns reflect inflows from Long Lake Creek, which did not vary greatly during the study (figs. 7, 8).

There was little variability in specific conductance among the six sample sites of Unit 2 with Unit 2, site 1 consistently having some of the lowest readings (fig. 14). This pattern may be because of mixing with the fresher water from Unit 1 through the B dike water-control structure, which was proximate to Unit 2 , site 1 . There was little variation among the three sites of Unit 2 Marsh for most of the study, but variability was high during 2008 and the latter parts of 2012 when water levels were extremely low, mixing was evidently incomplete, and salts were more concentrated (fig. 15). Unit 2 Marsh, site 3 was consistently lower than the other two sites located in Unit 2 Marsh during early parts of 2008 and the latter parts of 2012. This was likely because of mixing with fresher water from Unit 2 through the water-control structure near Unit 2 Marsh, site 3.

Unit 3 displayed little variation from 2009 to 2011, but readings from Unit 3, site 1 were slightly lower than the other sites likely because of its proximity to the C-dike water-control structure linking Units 2 and 3 (fig. 16). During 2012, specific conductance readings from Unit 3, sites 4 and 5 (located upstream in the tributary) were consistently lower than the other Unit 3 sites during the first part of the year. Specific conductance of Unit 3, site 4 gradually increased during the latter part of the year and the Unit 3, site 5 tributary went dry (fig. 16). The lower specific conductance of Unit 3, site 5 indicates that the tributary inflows were fresher than the receiving waters of Unit 3 . Unit 3 , site 4 also is affected by early-season inflows from Unit 3, site 5 and other tributaries located at the east part of Unit 3. These tributaries contributed water during 2009-12, but dried more quickly in 2009 through 2011 than 2012; thus, the low values of Unit 3, site 4 likely are the result of mixing with local inflows early in the year during peak flows. The cause of the late-season increase of Unit 3 , site 4 specific conductance values may be because of incomplete mixing and evaporative effects in the large bay of Unit 3 (fig. 2).

\section{Implications}

Water-quality data and seasonal patterns presented in this report provide information to support refuge management decisions by identifying potential water-quality problems that may affect aquatic habitats and the wetland-dependent species that rely on them. Water-quality data also can be used in conjunction with subsequent monitoring efforts to identify changes over time. From the water-quality data collected during 2008 through 2012, aluminum and copper appeared to have accumulated in refuge units over time (figs. 5, 6). Additionally, an inverse relation between specific conductance and water level was identified, with the largest specific conductance values observed during periods of low water levels (figs. 9-12). Continued monitoring of water levels, specific conductance, and general water-quality chemistry (specifically, aluminum) would support future water-management decisions by facilitating assessments of temporal patterns and the water quality of inflows (for example, Unit 3, site 5), and by identifying potential accumulation of chemical constituents. 


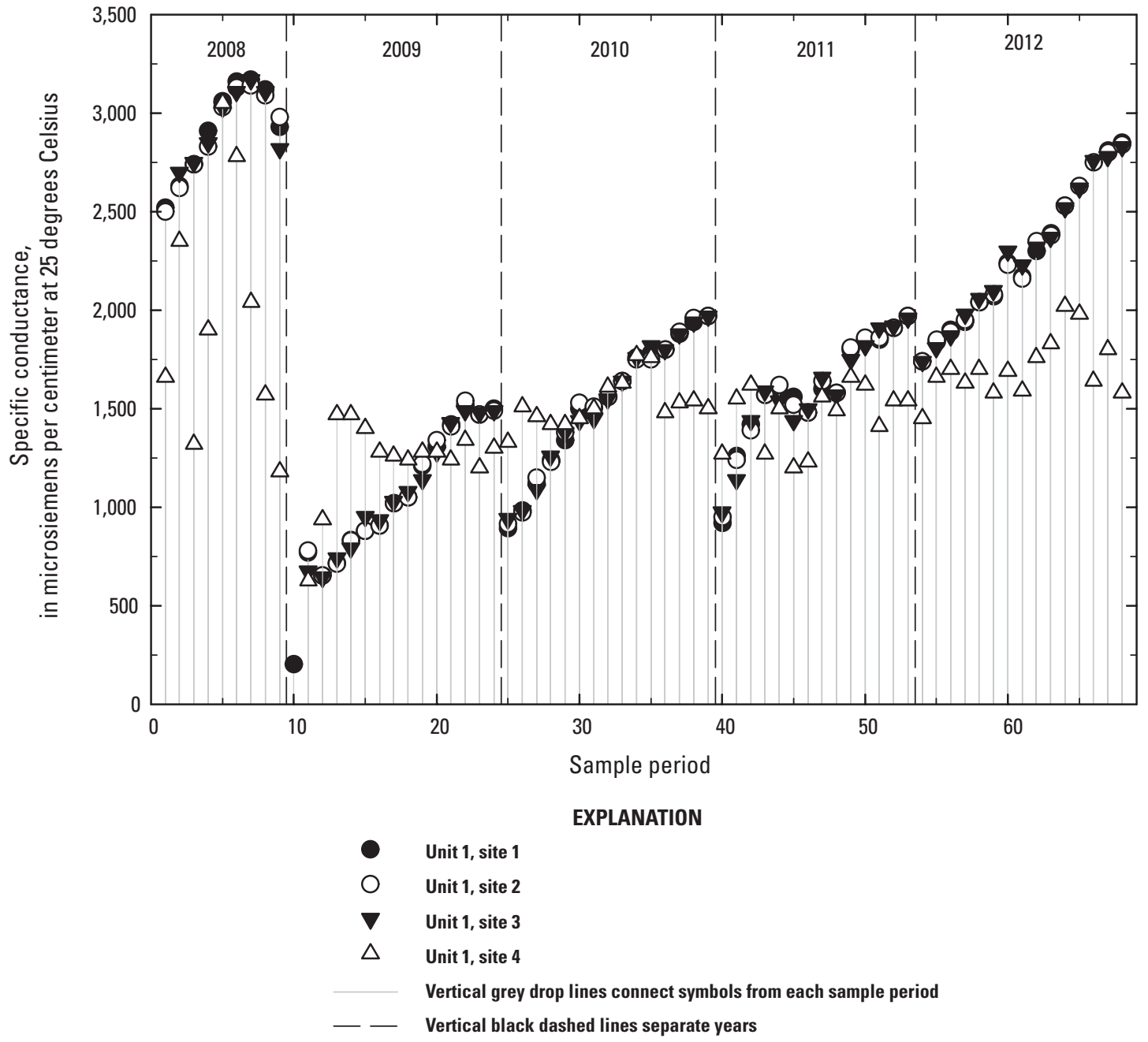

Figure 13. Specific conductance from water-quality samples collected across 68 sample periods for the 4 sample sites (symbols) distributed around Unit 1 of Long Lake National Wildlife refuge, 2008 through 2012.

The information provided in this report also can be used to evaluate and refine water-quality sampling to reduce costs. The observed specific conductance seasonal patterns and variability (figs. 9-12) demonstrate the need for long-term monitoring. Further, these patterns show the importance of collecting ancillary data, such as water level, to provide comparisons among time periods with similar characteristics (water level and volume) and provide better interpretation of data. For example, data from Long Lake indicate that making comparisons among time periods with similar water levels is important because seasonal changes in water level (evapoconcentration and dilution) can greatly affect water-quality properties such as specific conductance (figs. 9-12) and trace metals such as arsenic (fig. 17). For water-quality assessments at Long Lake NWR, it is evident that continued monitoring also is important because of the high potential for interannual variation (fig. 7). As an example, assessments using data collected during 2008 would lead to different conclusions than if they were founded on data collected during 2009. The consistent, gradual seasonal patterns of Long Lake suggest that the biweekly water-quality sample collection effort may be reduced and still provide the ability to assess the system. Based on patterns presented in figures 7-12, a seasonal (spring, mid-summer, fall) or monthly sampling effort likely would provide data sufficient to support refuge management. Moreover, if purchasing automated loggers for continuous measurement of specific conductance and water level is cost prohibitive, periodic measurements from hand-held loggers and staff gages can provide data with sufficient resolution to assess seasonal patterns. Comparisons between seasonal specific conductance reading from the in situ data loggers (fig. 7) and hand-held meters (fig. 18) indicate good concordance over the 5 years of this study. Further, the hand-held meter data presented in appendix 2 represent a 5-year period of record that can be used as a baseline for future comparisons. 


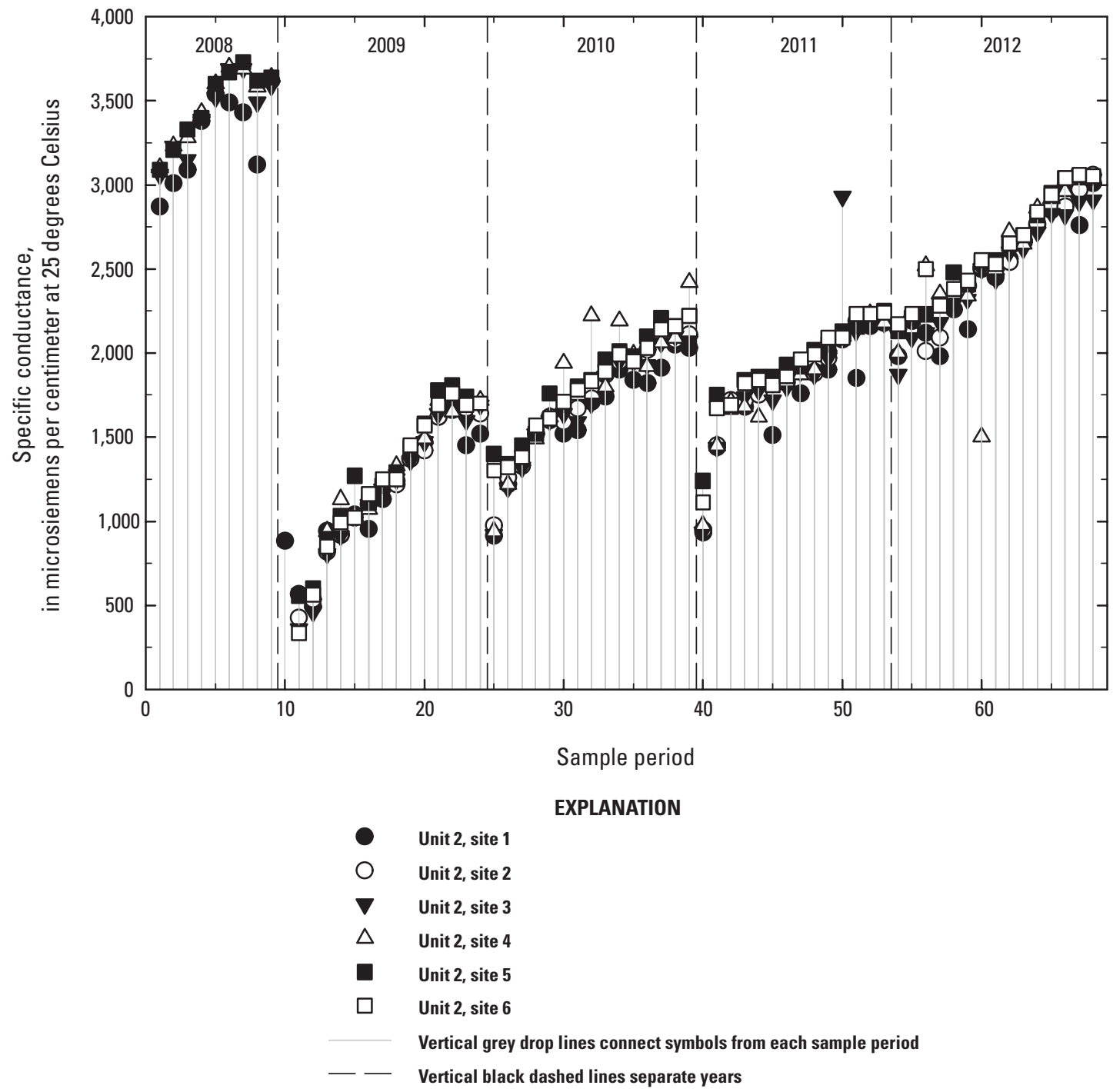

Figure 14. Specific conductance from water-quality samples collected across 68 sample periods for the 6 sample sites (symbols) distributed around Unit 2 of Long Lake National Wildlife refuge, 2008 through 2012.

Similar to the temporal patterns, assessments of withinunit spatial variation can be used to increase the efficiency of the Long Lake monitoring program. Data presented in figures 13-16 suggest the individual Long Lake management units are well mixed, and the number of sample sites could be reduced, while still providing sufficient information to refuge managers. It is apparent that each unit could be characterized sufficiently with a minimal number of spatially-distributed sample sites. Based on the data presented in figures 13-16, a minimum of one sample from each management unit is recommended as long as the locations are not affected by inflows [for example, Unit 1, site 4, (fig. 13); Unit 3, site 5 (fig. 16)] or mixing with other units through water-control structures. If the water-quality of inflows is of interest, or if there is available labor, additional sample locations could be added.

Ultimately, the primary purpose of monitoring water quality of NWR lakes and wetlands is to assess habitat suitability for target wildlife species such as waterfowl and other migratory birds. An important factor related to the suitability of refuge habitats for wetland-dependent birds is the makeup of the aquatic plant and invertebrate communities, which can be highly correlated with various water-quality properties such as salinity (Gleason and others, 2009). General comparisons between salinity data collected for this study and information presented by Gleason and others (2009) suggest most common taxa likely inhabiting Long Lake would not be negatively 


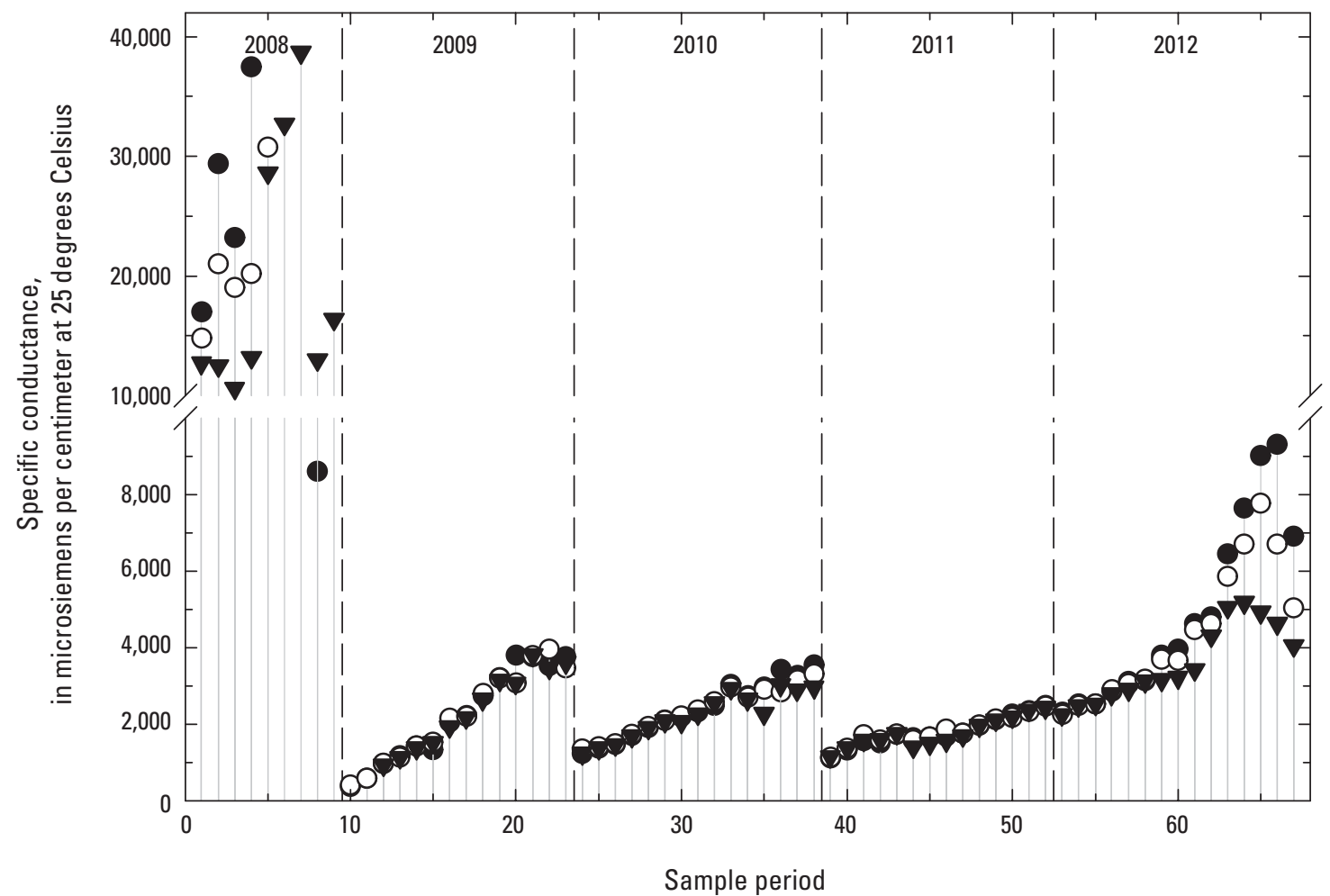

EXPLANATION

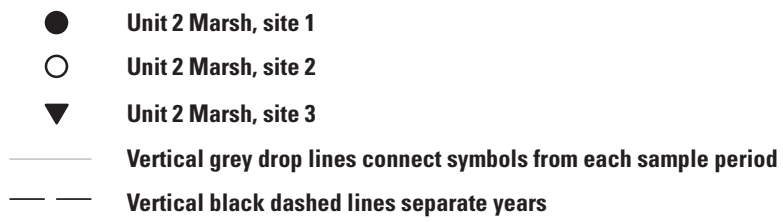

Figure 15. Specific conductance from water-quality samples collected across 67 sample periods for the 3 sample sites (symbols) distributed around Unit 2 Marsh of Long Lake National Wildlife refuge, 2008 through 2012.

affected by salinity levels during most years. Further, salinity values were typically lowest in the spring when birds hatch and many plants germinate. However, the observations suggest that extended drought, or management resulting in sustained low water levels, could result in prolonged periods of extremely high salinity in some units (for example, Unit 2 Marsh; fig. 11) that could have a negative effect on some plant and invertebrate taxa.

Based on the climate-related variability demonstrated by this study and the range of salinity tolerances exhibited by various aquatic biota (for example, Gleason and others, 2009) the ability to predict salinity levels for various climate scenarios would support future decisions concerning water management.
For example, various models have been presented for use in planning water management and predicting habitat conditions for NWRs based on water needs and availability (Hamilton and others, 1989; Kendy, 1999; Nimick and others, 2011; Tangen and others, 2013). These models provide useful tools for refuge managers and they require additional data relating to water balance, bathymetry, and water-management capabilities (Tangen and others, 2013). Therefore, information (including salinity tolerances) pertaining to the composition of aquatic plant and invertebrate communities, as well as data to support modeling efforts, would enhance the ability of USFWS personnel to manage lakes and wetlands for target species. 
Figure 16. Specific conductance from waterquality samples collected across 59 sample periods for the 5 sample sites (symbols) distributed around Unit 3 of Long Lake National Wildlife refuge, 2009 through 2012.

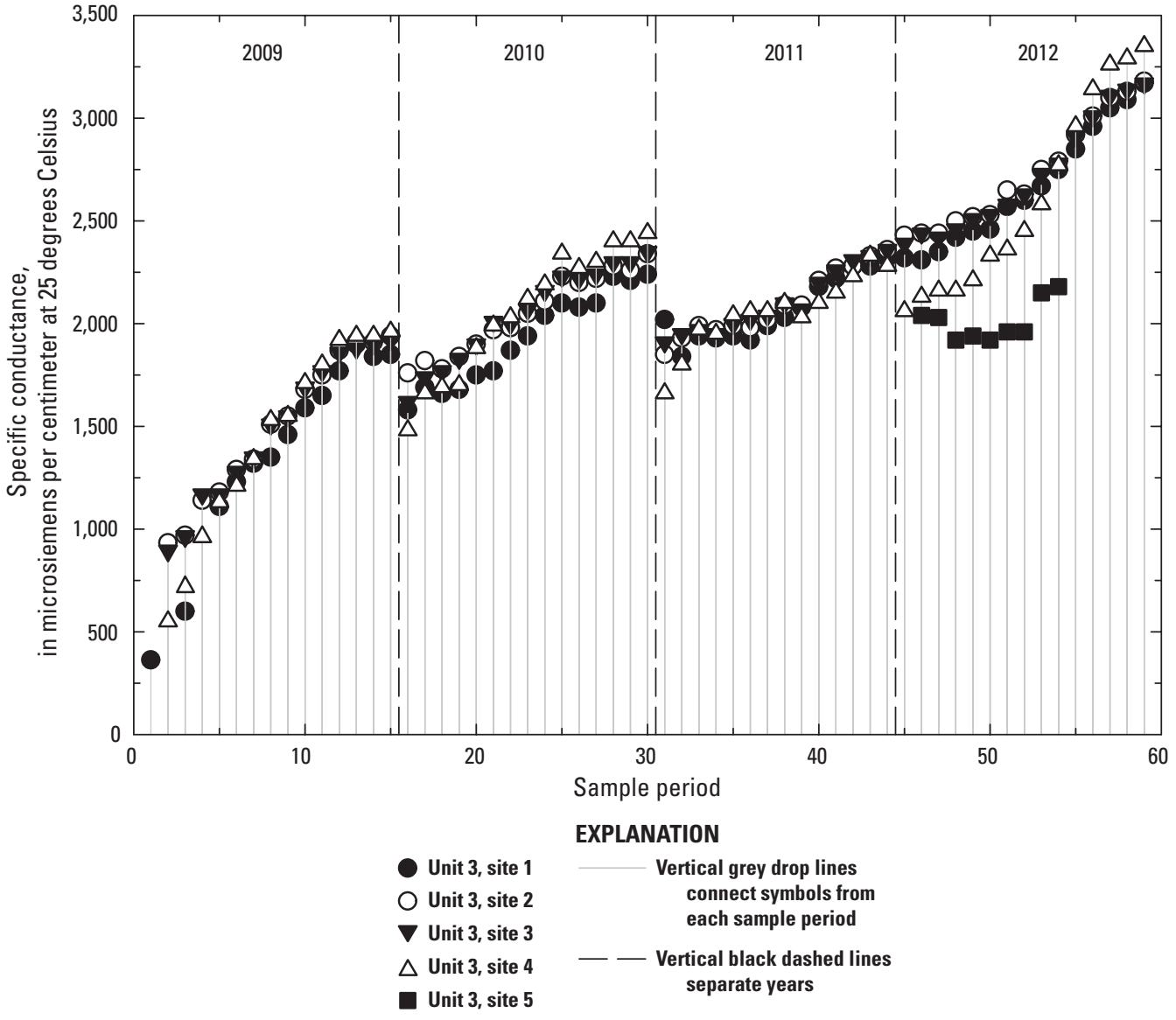

Figure 17. Mean arsenic concentrations from water-quality samples of Unit 1, Unit 2, Unit 2 Marsh, and Unit 3 of Long Lake National Wildlife Refuge, 2008 through 2012. Corresponding water-level and specific conductance values are presented in figures 9-12.

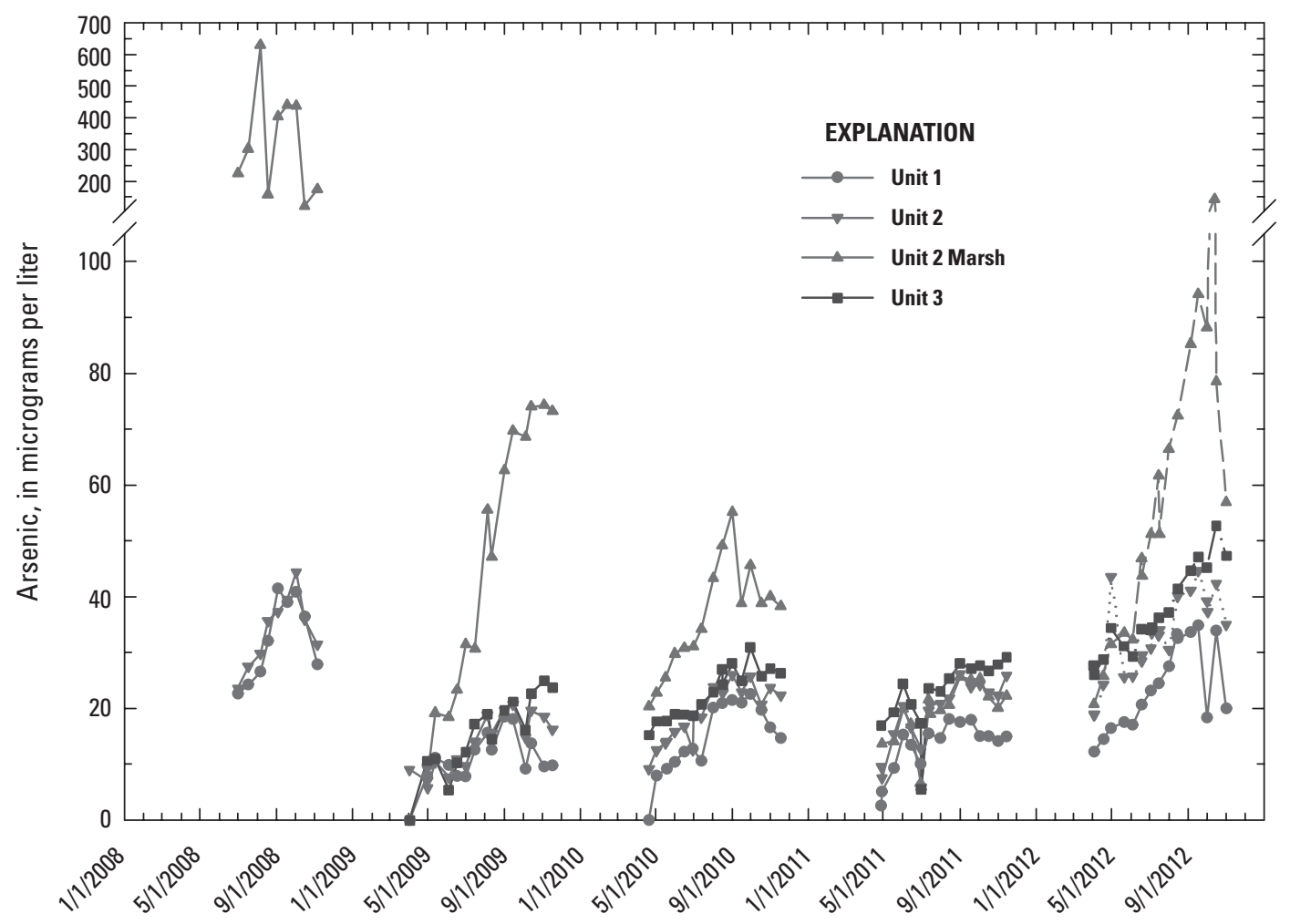




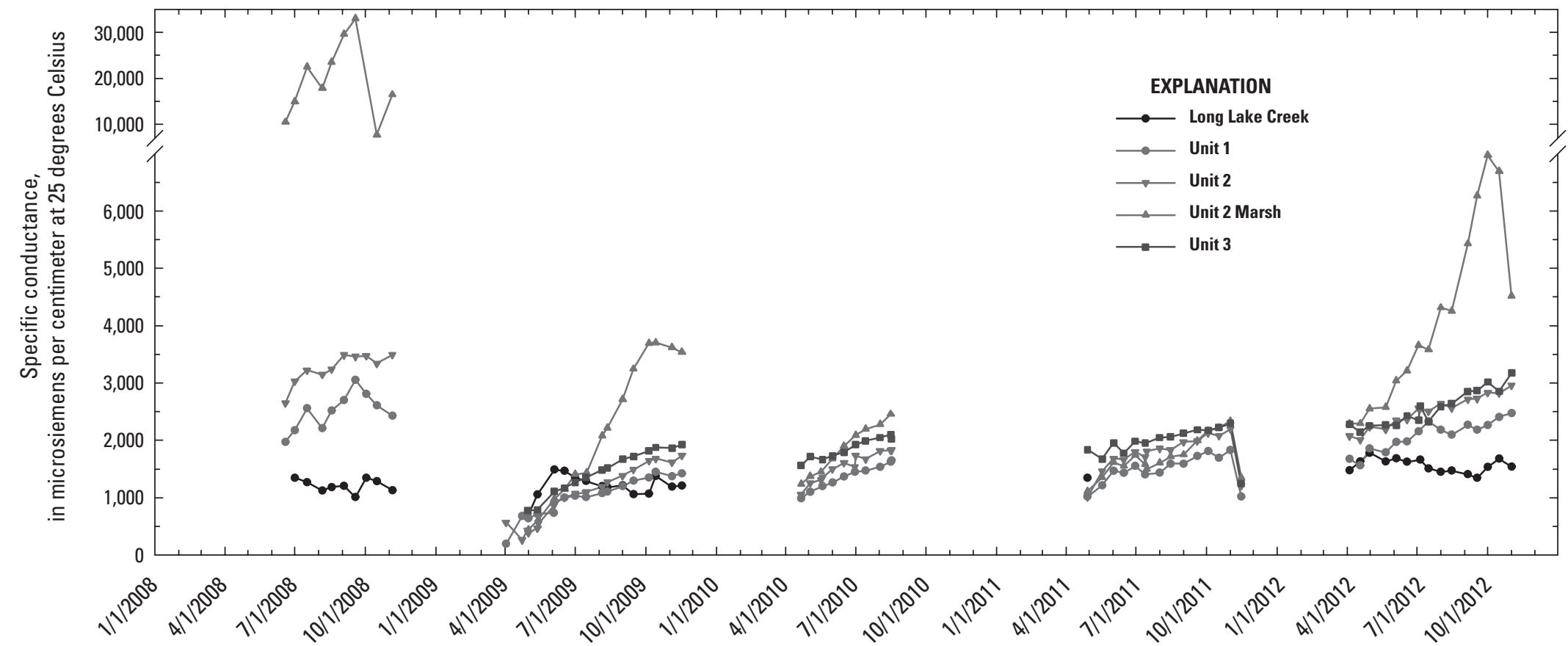

Figure 18. Specific conductance from hand-held loggers deployed at Long Lake Creek and Unit 1, Unit 2, Unit 2 Marsh, and Unit 3 of Long Lake National Wildlife Refuge, 2008 through 2012. 


\section{Summary}

There are widespread concerns about declining water quality of managed lakes and impoundments throughout the U.S. Fish and Wildlife Service, National Wildlife Refuge system. Many of these lakes and impoundments are fed by lotic systems, receive excess runoff from surrounding agricultural lands, and have been modified with dams, dikes, and water-control structures that allow for the retention of water and limit natural flushing events that can alleviate buildup of water-quality constituents. These concerns are most prominent in arid regions where negative precipitation:evaporation ratios can exacerbate water-quality problems by concentrating potentially harmful salts, trace metals, toxic elements, and agrichemicals.

High priority has been placed on assessing water quality throughout the National Wildlife Refuge system, but there is little information or guidance available pertaining to study design, methodology, and sample frequency. With this study, an intensive biweekly sample effort was completed across a spatially distributed set of sample locations at Long Lake National Wildlife Refuge over a 5 -year period. Water-quality data from this study were used to assess the current (2008 through 2012) state of the system, and will be used as modern baselines for future comparisons and assessments. Additionally, the design of this study allowed for an assessment of the temporal and spatial variability of water management units of Long Lake National Wildlife Refuge, which can help refine and guide future monitoring efforts not only at Long Lake National Wildlife Refuge, but at other refuges with similar attributes and water-quality concerns.

Summaries of ions, trace metals, and nutrient data presented in this report represent baseline water-quality conditions from 2008 through 2012. Although the historic data were limited in supporting a comprehensive assessment of past water-quality conditions, the data from this study provide information for future comparisons. Aluminum, arsenic, boron, copper, and sulfate regularly exceeded various state water-quality standards. Aluminum and copper also may be accumulating in Long Lake units. However, aluminum and copper levels are similar to other systems in the region and the reported levels are not a concern for aquatic life because these trace metals are largely insoluble in high $\mathrm{pH}$ systems such as Long Lake. Arsenic, boron, and sulfate only exceeded human health and drinking-water standards; thus, the levels are not of great concern at Long Lake, which is primarily used for wildlife.

Specific conductance was used as a representative property to identify and assess temporal and spatial variability in water quality. Consistent seasonal patterns of increasing specific conductance were related to seasonal water-level drawdown and evapoconcentration. The data indicate that specific conductance can vary greatly among years in relation to large spring runoff events. For the long-term, it is likely that similar interannual patterns will be linked to climatic cycles of drought and inundation. Spatial variability between management units was evident along a concentration (salinity) gradient from Unit 1 to Units 2 and 3 and Unit 2 Marsh. This concentration gradient was most evident during the extremely dry year of 2008. Conversely, there was little variability among the sample sites located within each water management unit when compared by sample collection period. The exceptions were sites located near areas of inflow or water-control structures connecting water management units. For example, Unit 1, site 4 was located near the mouth of Long Lake Creek where it discharges into the lake. Specific conductance at this site did not indicate the upward seasonal pattern characteristic of the other sites; instead, levels were more similar to those of Long Lake Creek during most of this study. Similarly, Unit 3, site 5 was located in a tributary and displayed lower specific conductance levels than the other Unit 3 sites.

Based on the observed temporal and spatial patterns it is evident that the current (2008 through 2012) sample design can be modified to reduce costs and labor requirements, while still providing sufficient data to inform management decisions. Modifications might be to reduce the sample frequency to a seasonal (spring, summer, fall) or monthly effort and to collect at least one sample from each management unit in a representative area that is not affected by inflows associated with local tributaries or water-control structures. Additional tributary sites may be added to provide assessments of specific areas.

Based on this and other studies, it is evident that concentrations of various water-quality properties vary in response to short- and long-term changes in water levels (that is, water volumes). Although salts, trace metals, and agrichemicals can accumulate or be removed over time, this study indicates that the short-term seasonal and interannual changes in these water-quality properties result primarily from concentration or dilution; therefore, researchers and refuge managers should consider this variability when designing monitoring efforts and when assessing water quality over time.

\section{References Cited}

Baskin, C.C., and Baskin, J.M., 1998, Seeds-ecology, biogeography, and evolution of dormancy and germination: San Diego, Calif., Academic Press, 666 p.

Briggs, J.C., and Ficke, J.F., 1977, Quality of rivers of the United States, 1975 water year-Based on the National stream Accounting Network (NASQAN): U.S. Geological Survey Open-File Report 78-200, 436 p.

DeVink, J-M.A., Gilchrist, H.G., and Diamond, A.W., 2005, Effects of water salinity on growth and survival of Common Eider (Somateria mollissima) Duckings: The Auk, v. 122, p. 523-529.

Eisenlohr, W.S., Jr., and others, 1972, Hydrologic investigations of prairie potholes in North Dakota-1959-68: U.S. Geological Survey Professional Paper 585-A, 102 p. 
Galloway, J.M., Vecchia, A.V., Vining, K.C., Densmore, B.K., and Lundgren, R.F., 2012, Evaluation of water-quality characteristics and sampling design for streams in North Dakota, 1970-2008: U.S. Geological Survey Scientific Investigations Report 2012-5216, 304 p.

Gensemer, R.W., and Playle, R.C., 1999, The bioavailability and toxicity of aluminum in aquatic environments: Critical Reviews in Environmental Science and Technology, v. 29, p. $315-450$.

Gleason, R.A., Tangen, B.A., Laubhan, M.K., Finocchiaro, R.G., and Stamm, J.F., 2009, Literature review and database of relations between salinity and aquatic biota - applications to Bowdoin National Wildlife Refuge, Montana: U.S. Geological Survey Scientific Investigations Report 2009-5098, $76 \mathrm{p}$.

Hamilton, D.B., Roelle, J.E., and Schafer, W.M., 1989, A simulation model of water and salt balance at Bowdoin National Wildlife Refuge: Fort Collins, Colo., U.S. Fish and Wildlife Service, National Ecology Research Center, NERC-89/08, 60 p.

Hammer, U.T., and Heseltine, J.M., 1988, Aquatic macrophytes in saline lakes of the Canadian prairies: Hydrobiologia, v. 158, p. 101-116.

Hem, J.D., 1985, Study and interpretation of the chemical characteristics of natural water: U.S. Geological Survey Water-Supply Paper 2254, 264 p.

Kendy, E., 1999, Simulation of water and salt budgets and effects of proposed management strategies for Bowdoin National Wildlife Refuge, northeastern Montana: Helena, Mont., U.S. Geological Survey Water-Resources Investigations Report 98-4260, 86 p.

LaBaugh, J.W., 1989, Chemical characteristics of water in northern prairie wetlands, in van der Valk, A., ed., Northern prairie wetlands: Ames, Iowa State University Press, p. 56-90.

LaBaugh, J.W., and Swanson, G.A., 2003, Spatial and temporal variability in specific conductance and chemical characteristics of wetland water and in water column biota in the wetlands in the Cottonwood Lake area, in Winter, T.C., ed., Hydrological, chemical, and biological characteristics of a prairie pothole wetland complex under highly variable climate conditions - the Cottonwood Lake area, eastcentral North Dakota: U.S. Geological Survey Professional Paper 1675, 109 p.

Laubhan, M.K., Gleason, R.A., Knutsen, G.A., Laubhan, R.A., and Euliss, N.H., Jr., 2006, A preliminary biological assessment of Long Lake National Wildlife Refuge Complex, North Dakota: U.S. Department of Interior, Fish and Wildlife Service, Biological Technical Publication, BTP R6006-2006, 66 p.
McLaren, R.G., and Crawford, D.V., 1973, Studies of soil copper I-The fractionation of copper in soils: Journal of Soil Science, v. 24, p.172-181.

Moorman, A.M., Moorman, T.E., Baldassarre, G.A., and Richard, D.M., 1991, Effects of saline water on growth and survival of Mottled Duck ducklings in Louisiana: Journal of Wildlife Management, v. 55, p. 471-476.

National Irrigation Water Quality Program, 1998, Guidelines for interpretation of the biological effects of selected constituents in biota, water, and sediment: Bureau of Reclamation, Denver, Colo., Information Report No. 3, 211 p., accessed June 1, 2013, at http://www.usbr.gov/niwqp/index. html.

National Oceanic and Atmospheric Administration, 2013, National Climatic Data Center web site, accessed April 1, 2013, at http://www.ncdc.noaa.gov/cag/time-series/us.

Nimick, D.A., McCarthy, P.M., and Fields, Vanessa, 2011, A digital model for planning water management at Benton Lake National Wildlife Refuge, west-central Montana: U.S. Geological Survey Scientific Investigations Report 2011-5133, 28 p.

North Dakota Department of Health (NDDH), 2012a, NDDH web site, accessed July 1, 2012, at http://www.ndhealth.gov/ WQ/SW/Z6_WQ_Standards/B_WQ_Monitoring.htm.

North Dakota Department of Health, 2012b, Standards of quality for waters of the State, North Dakota Century Code 33-16, accessed July 1, 2012, at http://www.ndhealth.gov/ WQ/SW/Z6_WQ_Standards/B_WQ_Standards.htm.

North Dakota Department of Health, 2013, Chemistry laboratory quality assurance program-January 2013 revision: Bismarck, N. Dak., North Dakota Department of Health, Laboratory Services Division, 43 p.

Olson, M.M., and Welsh, D., 1991, An investigation into the water quality of Long Lake National Wildlife Refuge, Burleigh and Kidder Counties, North Dakota: Bismarck, N. Dak., U.S. Fish and Wildlife Service, Environmental Contaminants Program.

Omernik, J.M., Griffith, G.E., Irish, J.T., and Johnson, C.B., 1988, Total alkalinity of surface waters-a national map: Corvallis, Oreg., Environmental Research Laboratory, U.S. Environmental Protection Agency.

Ryberg, K.R., and Hiemenz, Gregory, 2009, Summary and analysis of water-quality data for the Arrowwood National Wildlife Refuge, east-central North Dakota, 1987-2004: U.S. Geological Survey Scientific Investigations Report 2009-5017, 92 p. 
Schwarz, M.S., Echols, K.R., Wolcott, M.J., and Nelson, K.J., 2004, Environmental contaminants associated with a swine concentrated animal feeding operations and implications for McMurtrey National Wildlife Refuge: U.S. Fish and Wildlife Service, Environmental Contaminants Program Report 6N45, $97 \mathrm{p}$.

Sparling, D.W., Lowe, T.P., and Campbell, P.G.C., 1996, Ecotoxicology of aluminum to fish and wildlife, in Yokel, R.A., and Golub, M.S., eds., Research issues in aluminum toxicity: Washington, D.C., Taylor \& Francis, p. 47-67.

Stewart, R.E., and Kantrud, H.A., 1972, Vegetation of prairie potholes, North Dakota, in relation to quality of water and other environmental factors: U.S. Geological Survey Professional Paper 585-D, 36 p.

Swanson, G.A., Adomaitis, V.A., Lee, F.B., Serie, J.R., and Shoesmith, J.A., 1984, Limnological conditions influencing duckling use of saline lakes in south-central North Dakota: Journal of Wildlife Management, v. 48, p. 340-349.

Swanson, G.A., Winter, T.C., Adomaitis, V.A., and LaBaugh, J.W., 1988, Chemical characteristics of prairie lakes in south-central North Dakota - their potential for influencing use by fish and wildlife: Washington, D.C., U.S. Fish and Wildlife Service, Fish and Wildlife Technical Report 18, $44 \mathrm{p}$.

Tangen, B.A., Gleason, R.A., and Stamm, J.F., 2013, A model for evaluating effects of climate, water availability, and water management on wetland impoundments - A case study on Bowdoin, Long Lake, and Sand Lake National Wildlife Refuges: U.S. Geological Survey Scientific Investigations Report 2013-5114, 37 p., at http://pubs.usgs.gov/ sir/2013/5114/.

Tisdale, S.L., and Nelson, W.L., 1975, Soil fertility and fertilizers: New York, N.Y., Macmillan Publishing Company., $694 \mathrm{p}$.

University of Wisconsin-Madison, 2013, Space Science and Engineering Center, Cooperative Institute for Meteorological Satellite Studies Blog, accessed April 1, 2013, at http:// cimss.ssec.wisc.edu/goes/blog/archives/760.
U.S. Environmental Protection Agency, 1986, Quality criteria for water-1986: Office of Water Regulations and Standards, Washington, D.C., EPA 440/5-86-001, 477 p.

U.S. Environmental Protection Agency, 1988, Ambient water quality criteria for Aluminum-1988: Washington, D.C., Office of Water Regulations and Standards, Criteria and Standards Division, EPA 440/5-86-008, 47 p.

U.S. Environmental Protection Agency, 2000a, Ambient water quality criteria recommendations-information supporting the development of state and tribal nutrient criteria for lakes and reservoirs in nutrient ecoregion VI: Washington, D.C., Office of Water, Office of Science and Technology, Health and Ecological Criteria Division, EPA 822-B-00-008, 73 p.

U.S. Environmental Protection Agency, 2000b, Methodology for deriving ambient water quality criteria for the protection of human health: Washington, D.C., Office of Water, Office of Science and Technology, EPA-822-B-00-004, 166 p.

U.S. Environmental Protection Agency, 2007, Aquatic life ambient freshwater quality criteria-copper: Washington, D.C., Office of Water, Office of Science and Technology, EPA-822-R-07-001, 195 p.

U.S. Fish and Wildlife Service, 2006, Comprehensive conservation plan: Long Lake National Wildlife Refuge Complex: Lakewood, Colo., U.S. Department of the Interior, Fish and Wildlife Service, Mountain-Prairie Region, 251 p.

U.S. Fish and Wildlife Service, 2012, Long Lake National Wildlife Refuge web site, accessed July 1, 2012, at http:// www.fws.gov/longlake/.

U.S. Salinity Laboratory Staff, 1954, Diagnosis and improvement of saline and alkali soils: U.S. Department of Agriculture Handbook 60, 160 p.

Wetzel, R.G., 2001, Limnology-lake and river ecosystems (3d ed.): San Diego, Calif., Academic Press, 1,006 p. 
Publishing support provided by:

Rolla and Denver Publishing Service Centers

For more information concerning this publication, contact: Director, Northern Prairie Wildlife Research Center U.S. Geological Survey 8711 37th Street Southeast Jamestown, North Dakota 58401 (701) $253-5500$

Or visit the Northern Prairie Wildlife Research Center Web site at: http://www.npwrc.usgs.gov/ 


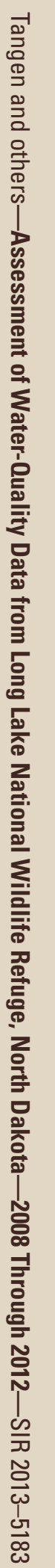

